\title{
USE OF GAMMA-RAY AND TWO OF CHEMICAL MUTAGENS TO INDUCE GENETIC VARIANCES IN TWO GARLIC CULTIVARS \\ Hemada, A. A. ${ }^{1}$; S. I. Ahmed ${ }^{1}$ and A.G. Mohamed ${ }^{2}$ \\ ${ }^{1}$ Vegetable Res. Dept., Hort. Res. Inst., Agric. Res. Center, Giza, Egypt \\ ${ }^{2}$ Breeding Res. Dept., Hort. Res. Inst., Agric. Res. Center, Giza, Egypt
}

\begin{abstract}
This work was carried out in two winter seasons plantations of 2010 and 2011 on garlic at sids Horticulture Research, A. Research center Benisuif Governorate. which does not compose seeds under normal growing conditions to improve the crop by mutations breeding, clove seeds of two cultivars of garlic; Balady and Egaseed-1 were exposed, before planting, to five different doses of gamma-rays $(1,3,5,10$ and $15 \mathrm{~Gy})$. Also, the second part from the same clove seeds were treated with four levels of di-ethyel sulphate (DES) and di (2-chloro ethyel) amine (DEA) $(0.05,0.1,0.2$ and $0.3 \%)$. The effect of these treatments on some characteristics were evaluated in the first (M1V1) and second (M1V2) mutant-vegetative generation. Generally, it was found that, higher doses of gamma-irradiation decreased the studied growth, yield and its components, chlorophyll $a, b$ and carotenoids when compared with the untreated plants in the two cultivars. The high concentrations of DES and DEA mutagens increased most of the studied characteristics in the M1V1 and M1V2 in both generations. In the mutants, low concentration of DES and DEA increased most of the studied characters in the M1V1 generation in both cultivars. The higher magnitudes of the range values in most of the evaluated characters such as number of cloves per bulb, bulb diameter, clove size and fresh and cured yield were detected, reflecting the genetic differences among the tested treatments for these characters in both cultivars. Based on the correlation studies, the improvement in number of leaves, plant height and bulb diameter will bring simultaneous improvement of garlic yield in both Balady and Eggaseed populations.
\end{abstract}

\section{INTRODUCTION}

Egyptions used garlic for both cooking and jaundice during the post decade, there has been a growing awareness of its potential medical uses. Only three new colored cultivars (Sids-40, Eggaseed-1 and Eggaseed-2) have been developed since more than ten years due to its sterility. Thus induced mutations serve as a complementary approach in genetic improvement of such crops through supplementing the existing germplasm by creating genetic variability (Shu, 2009). Mutagenesis especially gamma rays and ethylmethan sulfonate (EMS) may be considered a reliable alternative breeding methods (Batchvarov, 1993). In Egypt, Shalaby et al. (1983 a and b) found that in the M2 generation gamma radiation and EMS treatments increased the variability of garlic plants with respect to some characters, such as bulb weight, clove weight and harvest time. Alvarez, et al. (1996) reported that different doses from gamma-ray induced different phenotypic variations in the second mutant (M2) garlic population. Also, Kumar and Tiwari (1998) mentioned that various doses of gamma-ray in some garlic genotypes increased the time period from sprout and harvest but reduced plant height, 
Hemada, A. A. et al.

leaf length, number of leaves and neck diameter of bulb in M1. Iglesias et al. (2001) found that higher doses (80-90 Gy) of gamma-irradiation in garlic and onion inhibited the germinations. Shashidhar et al. (2005) showed that on garlic the survival percentage decreased with increasing the dose of gamma radiation. Metwally and Abou Shousha (2002) and Al-Safadi et al. (2003) evaluated several mutants for garlic yield and its components. However, it is very important to determine suitable mutagen dose for improving crops by mutation breeding (Joshi et al., 2011). In such vegetative-propagated crops, the treated cloves is called the M1V1, the next generation being M2V2, and so on (Acquaah, 2012).

Correlation coefficients are useful parameter in developing suitable selection criteria for chosen desired type or developing high yield cultivars (Agrawal et al., 2003) and Ammar (2007). In garlic, high positive correlations of bulb yield with leaf length and plant height were observed by Raj and Khan (2002) and Metwally and El-Denary (2003). In mutation breeding to ensure a reasonable change in the recovery of a desired kind of mutant the surviving M1V1 population is critically important. However, the potential of different mutagens in inducing quantitative variation was measured in early generation (M1V1 and M1V2) by simple measurements of variability, i.e. range, mean and variance (Novak,1991).

In Egypt, developing new garlic materials requires special consideration due to the importance of this crop to the Egyptian farmers and national incomes. The main objectives of the present to study the effect of different doses of gamma-rays, different levels of di-ethyel sulphate (DES) and di (2-chloro ethyel) amine (DEA) on some growth chracteristics, yield and its components in two garlic cultivars .

\section{MATERIALS AND MOTHODS}

The experiments were carried out at the Experimental Farm of Sids Horticulture Research, Agriculture Research Center, Beni-Suef Governorate, Egypt, during the two winter seasons of 2010/2011 and 2011/2012. For raising the first mutant generation for this vegetative reproduction crop; large clove seeds of two commercial cultivars of garlic Balady and Egaseed-1 were exposed to Gy. Gamma-radiation five different doses of gamma-rays i.e. 1, 3, 5,10 and 15 source was cobalt-60 and the time of exposure was 20 mints ( $G y=100 \mathrm{rad}$ ). These treatments were done at the National Center of Research Dokki, Cairo, Egypt. Also, large clove seeds of the same garlic cultivars were soaking freshly prepared aqueous solution of di-ethyel sulphate (DES) and di (2-chloro ethyel) amine (DEA). The concentrations of the two chemical mutagens were $0.05,0.1,0.2$ and 0.3 for 12 hours at room temperature followed by washing under running tap water for one hour. Untreated cloves (control).

Garlic clove seeds were planted in field experiments to evaluate the performance of the first mutant generation (M1V1) of both cultivars in separate experiment. For each cultivar, Randomized Complete Blocks design with three replications was used. 
Each plot area was $10.5 \mathrm{~m}^{2}$ and which included consisted of 5 rows with $60 \mathrm{~cm}$ width and $3.5 \mathrm{~m}$ length. Garlic clove seeds cultivars were planted on the $10^{\text {th }}$ of October. Cloves seed were planted on both sides of each ridges at $10 \mathrm{~cm}$ apart.

For raising the second mutant vegetative generation (M1V2), largest cloves of M1V1 bulbs which showed positive deviation in mean values of control were selected at the planting time,. These cloves were bulked and thoroughly mixed and sown to obtain the second mutant generation. Three replications per treatment for each cultivar were maintained in separate experimental field as previously mentioned in the first mutant generation.

\section{Data recordred:}

\section{Vegetative growth parameters}

Ten plants were taken randomly from each plot at 40 days from planting to determine ,germination percentage ,at 40 days for measuring plant high $(\mathrm{cm})$, number of leaves / plant and neck diameter $(\mathrm{cm})$.

\section{Pigments content}

Total chlorophyll a, b and carotenoids were extracted by grinding 100 $\mathrm{mg}$ fresh leaves in a mortar with $10 \mathrm{~cm}^{3}$ acetone and measured at 663, 644 and $452 \mathrm{Nm}$ using the spectrophotometer. Calculation were derived using methods described by Robbelen (1957).

\section{Yield and its component}

\subsection{Total yield :}

Garlic plants were harvested in the $14^{\text {th }}$ and $20^{\text {th }}$ of April in the seasons and the total yield $(\mathrm{kg} / \mathrm{plot})$ both to ton/fed.

\subsection{Cured yield then calculated.}

The harvested garlic plants were left in the open field to be cured for 21 days. The cured plants were then weighted and cured yield as ton per feddan. was determined.

\section{3 yield components}

Ten plants from each experimental plot were randomly taken to determine; cured bulb diameter $(\mathrm{cm})$, cured bulb weight $(\mathrm{g})$, clove weight $(\mathrm{g})$, number of cloves/bulb.

\section{Simple correlation coefficients}

The phenotypic correlation coefficients between fresh and cured yield with each of the other studied traits were computed for each cultivar in the first and second mutant generations .

\section{Statistical analysis}

Mean values of each trait were subjected to the analysis of variance to test the significance as described by Gomez and Gomez (1984). Duncan means separation test and correlations were detected by using MSTAT C Ver. 4 software (MSTAT C, 1985).

\section{RESULTS AND DISCUSSION}

The effect of treatments with gamma-rays, di-ethyl sulphate (DES) and di(2-chloro ethyl) amine (DEA) in the first (M1V1) and second (M1V2) generations were estimated by observing the following characteristics: 
Hemada, A. A. et al.

\section{Vegetative growth}

\subsection{Percentage of germination}

The magnitudes of range for cvs. Balady and Egaseed- 1 populations in the M1V1 and M1V2 were recorded in( Tables 1 and 2), data in Tables 3 and 4 showed that there were highly significant differences among the treatments in M1V1 and M1V2. Germination after 40 days from planting was decreased in both cultivars percentage while increment the dose of mutagens (gamma-rays, DES and DEA). The reduction was differed in the M1V1 and M1V2 in both cultivars. A considerable reduction was occurred when a dose of 10 Gy and above was used in both M1V1 and M1V2 but the M1V2 gave the highest values after 40 days from planting. These results are agreement in agreement with those obtained by Iglesias (2001) who found that higher doses (80-90Gy) of gamma-irradiation in garlic and onion inhibited the germinations. This inhibition effect may be due to increased rate of cell division and/or cell elongation as stated before in tomato by Badr et al., 1978. However, Duhova et al.(1990) found that the mutagens induced chromosome aberrations and these aberrations were increased with increasing the mutagen concentration.

\subsection{Plant height .}

Mutants exhibited a wider range of plant height in Balady and Egaseed-1cultivars (Table 1 and 2). The plant height values of cv. Balady ranged from 12 to $100 \mathrm{~cm}$ in the M1V1 and from 45 to $105 \mathrm{~cm}$ in the M1V2 where the values in cv. Egaseed-1 ranged from $15-94$ and $38-104 \mathrm{~cm}$ in M1V1 and M1V2, respectively. The effect of different treatments on the plant height was significant in the M1V1and M1V2 populations of both cultivars. Plant height was decreased with increasing the dose of gamma-rays in M1V1 and M1V2 generations at the same time, it was decreased by using DES and DEA but only in M1V1. The plant height was increased in the two populations with increasing the dose of DES and DEA in M1V2 generation. In both cultivars a considerable reduction was occurred when a dose of 10 Gy and above was used in M1V1 and M1V2. Using DEA at $0.3 \%$ gave the highest values of plant height treatments with non significant differences from $0.2 \%$ DEA in the M1V2 populations.. The stimulative effect of low dosage of gamma-rays on growth may be due to increasing cell length, cell number. These could shift the metabolism by promoting and stimulating the effect of phytohormones on the biosynthesis of nucleic acids (Hammad et al., 1988).

\subsection{Number of leaves.}

The maximum number of leaves per plant was recorded in cv. Balady by used chemical mutagens in M1V1 (Tables 1 and 2). It was 12 leaves in Egaseed-1 population at 1 gamma-rays (Gy). The number of leaves/plant for the two cultivars under study was decreased by using gamma-rays, DES and DEA in M1V1 (Tables 3 and 4). The results showed that significant differences among treatments and untreated (original cultivars) were observed. A highly significant decrease was found at 15 Gy in M1V1 and M1V2. While, the number of leaves/plant was increased in both cultivars with using high dose of DES and DEA in M1V2 generation only. DEA treatments only gave a high value for number of leaves/plant not significant differences between $0.2 \%$ DEA and $0.3 \%$ DEA in M1V2. These results are nearly in 
agreement with those obtained by Alvarez, et al, (1996) who reported that, different doses from gamma-ray induced different phenotypic variations in the M1V2 garlic populations.

\subsection{Neck diameter.}

Neck diameter values were smaller in cv. Balady population than in cv. Egaseed-1 (Tables 1 and 2). The range values over all treatments in Balady was $0.2-1.6$ and $0.8-1.7 \mathrm{~cm}$ in the $\mathrm{M} 1 \mathrm{~V} 1$ and $\mathrm{M} 1 \mathrm{~V} 2$, respectively. On the other side, these values in cv. Egaseed-1 were 0.2 to 1.9 and 0.5 to $2.3 \mathrm{~cm}$ in M1V1 and M1V2, respectively. The neck diameter was decreased with increasing gamma-rays, DES and DEA in the two studied cultivars as compared to the original cultivars in M1V1 only in (Tables 3 and 4). In both cultivars, high significant decrease was found by using 15 Gy treatments in M1V1 and M1V2. The $0.05 \%$ DES treatment caused high significant increase in neck diameter compared to the original in M1V1 while the $0.3 \%$ DES gave high significant increase in neck diameter than the other original cultivar in M1V2. These results in agreement with those obtained by Kumar and Tiwari (1998) who mentioned that, various doses of gamma-ray in some garlic genotypes reduced neck diameter of bulb in the first vegetative-mutant generation (M1V1).

Table 1. Range values of some growth characteristics in garlic; cv. Balady cultivar in the first (M1V1) and second (M1V2) mutant-vegetative generations which were exposed to gamma-rays (gy), di-ethyl sulphate (DES) and di(2-chloro ethyl) amine (DEA).

\begin{tabular}{|c|c|c|c|c|c|c|c|c|}
\hline \multirow[t]{2}{*}{ Treatments } & \multicolumn{2}{|c|}{ Germination $\%$} & \multicolumn{2}{|c|}{$\begin{array}{l}\text { Plant height } \\
\text { (cm) }\end{array}$} & \multicolumn{2}{|c|}{$\begin{array}{c}\text { Number of } \\
\text { leaves / plant }\end{array}$} & \multicolumn{2}{|c|}{$\begin{array}{c}\text { Neck diameter } \\
(\mathrm{cm})\end{array}$} \\
\hline & M1V1 & M1V2 & M1V1' & M1V2 & M1V1 & M1V2 & M1V1 & M1V2 \\
\hline $1 \mathrm{~Gy}$ & $87-90$ & $95-97$ & $72-81$ & $82-89$ & $8-10$ & $9-11$ & 1.1-1.3 & 1.3-1.6 \\
\hline $3 \mathrm{~Gy}$ & $59-68$ & $91-96$ & $69-74$ & $72-78$ & $8-9$ & $9-11$ & $0.9-1.4$ & $1.3-1.6$ \\
\hline 5 Gy & $44-48$ & $90-95$ & $54-68$ & $64-72$ & $7-9$ & $9-10$ & $0.7-1.3$ & 1.3-1.5 \\
\hline $10 \mathrm{~Gy}$ & $38-41$ & $87-92$ & $32-54$ & $58-64$ & $5-7$ & $7-9$ & $0.5-0.8$ & 1.1-1.5 \\
\hline $15 \mathrm{~Gy}$ & $4-5$ & $85-90$ & $12-38$ & $45-49$ & $4-6$ & $5-7$ & $0.2-0.9$ & $0.8-1.5$ \\
\hline $0.05 \%$ DES & $83-88$ & $94-98$ & $79-92$ & $74-88$ & $8-10$ & $8-11$ & $0.9-1.4$ & $1.0-1.5$ \\
\hline $0.1 \%$ DES & $74-80$ & $89-94$ & $74-87$ & $80-89$ & $8-10$ & $9-11$ & $0.8-1.3$ & $1.0-1.5$ \\
\hline $0.2 \%$ DES & $67-73$ & $86-91$ & $68-78$ & $89-105$ & $8-9$ & $9-12$ & $0.8-1.5$ & $1.0-1.6$ \\
\hline $0.3 \%$ DES & $58-64$ & $78-85$ & $63-76$ & $85-98$ & $7-9$ & $10-12$ & $0.7-1.2$ & 1.3-1.7 \\
\hline $0.05 \%$ DEA & $85-90$ & $92-97$ & $82-92$ & $81-93$ & $9-11$ & $10-12$ & $0.7-1.5$ & $0.8-1.5$ \\
\hline $0.1 \%$ DEA & $74-90$ & $89-93$ & $77-86$ & $88-96$ & $8-10$ & $10-12$ & $0.6-1.4$ & $1.0-1.4$ \\
\hline $0.2 \%$ DEA & $60-65$ & $85-90$ & $73-80$ & $87-97$ & $8-10$ & $10-12$ & $0.6-1.6$ & $1.0-1.5$ \\
\hline $0.3 \%$ DEA & $59-66$ & $80-84$ & $66-73$ & $90-105$ & $7-9$ & $10-12$ & \begin{tabular}{|l}
$0.6-1.2$ \\
\end{tabular} & 1.1-1.7 \\
\hline $\begin{array}{l}\text { Original cultivar } \\
\text { Balady }\end{array}$ & $95-100$ & $97-100$ & $79-100$ & $83-98$ & $9-11$ & $9-11$ & 1.0-1.5 & $1.1-1.5$ \\
\hline $\begin{array}{l}\text { Polled data over } \\
\text { all treatments }\end{array}$ & $4-100$ & $78-100$ & $12-100$ & $45-105$ & $4-11$ & 5-12 & $9-1.6$ & $0.8-1.7$ \\
\hline
\end{tabular}


Hemada, A. A. et al.

Table 2. Range values of some growth characteristics in garlic; cv. Egaseed-1 cultivar in the first (M1V1) and second (M1V2) mutant-vegetative generations which were exposed to gammarays (gy), di-ethyl sulphate (DES) and di(2-chloro ethyl) amine (DEA).

\begin{tabular}{|l|c|c|c|c|c|c|c|c|}
\hline \multirow{2}{*}{\multicolumn{1}{|c|}{ Treatments }} & \multicolumn{2}{|c|}{ Germination\% } & \multicolumn{2}{c|}{$\begin{array}{c}\text { Plant height } \\
\text { (cm) }\end{array}$} & \multicolumn{2}{c|}{$\begin{array}{c}\text { Number of } \\
\text { leaves / plant }\end{array}$} & \multicolumn{2}{c|}{$\begin{array}{c}\text { Neck diameter } \\
\text { (cm) }\end{array}$} \\
\cline { 2 - 9 } & M1V1 & M1V2 & M1V1 & M1V2 & M1V1 & M1V2 & M1V1 & M1V2 \\
\hline 1 Gy & $88-93$ & $96-99$ & $61-84$ & $79-85$ & $9-11$ & $9-12$ & $0.7-1.2$ & $1.0-1.8$ \\
\hline 3 Gy & $80-85$ & $93-96$ & $64-78$ & $68-77$ & $8-9$ & $8-11$ & $0.6-1.0$ & $1.0-1.4$ \\
\hline 5 Gy & $60-65$ & $91-95$ & $54-67$ & $60-70$ & $7-9$ & $9-11$ & $0.5-0.9$ & $0.6-1.2$ \\
\hline 10 Gy & $36-40$ & $90-93$ & $30-40$ & $50-58$ & $5-7$ & $8-10$ & $0.5-0.7$ & $0.5-1.2$ \\
\hline 15 Gy & $2-3$ & $88-91$ & $15-35$ & $38-51$ & $5-6$ & $8-9$ & $0.2-0.6$ & $0.6-1.0$ \\
\hline $0.05 \%$ DES & $90-95$ & $93-96$ & $64-76$ & $72-81$ & $7-8$ & $7-9$ & $1.1-1.9$ & $1.2-2.2$ \\
\hline $0.1 \%$ DES & $84-94$ & $89-93$ & $55-75$ & $61-80$ & $7-9$ & $8-9$ & $1.2-1.8$ & $1.4-1.9$ \\
\hline $0.2 \%$ DES & $77-84$ & $87-90$ & $60-71$ & $74-84$ & $7-8$ & $9-9$ & $1.1-1.7$ & $1.5-2.3$ \\
\hline $0.3 \%$ DES & $68-76$ & $77-84$ & $47-69$ & $78-93$ & $7-9$ & $8-10$ & $1.1-1.3$ & $1.5-2.2$ \\
\hline $0.05 \%$ DEA & $88-94$ & $91-94$ & $77-94$ & $81-93$ & $8-9$ & $8-10$ & $1.1-1.7$ & $1.0-1.7$ \\
\hline $0.1 \%$ DEA & $78-86$ & $88-93$ & $74-86$ & $83-92$ & $8-9$ & $9-10$ & $1.0-1.7$ & $1.2-1.7$ \\
\hline $0.2 \%$ DEA & $72-80$ & $85-89$ & $70-78$ & $87-104$ & $6-8$ & $9-11$ & $1.0-1.6$ & $1.2-1.8$ \\
\hline $0.3 \%$ DEA & $70-75$ & $75-82$ & $57-74$ & $87-104$ & $5-6$ & $9-11$ & $1.0-1.4$ & $1.3-1.8$ \\
\hline $\begin{array}{l}\text { Original cultivar } \\
\text { Eggaseed-1 }\end{array}$ & $94-100$ & $95-100$ & $76-89$ & $76-89$ & $8-11$ & $8-11$ & $1.0-1.5$ & $1.0-1.7$ \\
\hline $\begin{array}{l}\text { Polled data overall } \\
\text { treatments }\end{array}$ & $2-100$ & $77-100$ & $15-94$ & $38-104$ & $5-11$ & $8-12$ & $0.2-1.9$ & $0.5-2.3$ \\
\hline
\end{tabular}

\section{Gy: gamma-rays.}

DES: di-ethyl sulphate

DEA: di(2-chloro ethyl) amine.

Table 3. Effect of treatments by gamma-rays and di-ethyl sulphate (DES) and di(2-chloro ethyl) amine (DEA) on some vegetative parameters of garlic cultivar "Balady" in M1V1 in 2010/ 2011 and M1V2 in 2011/2012.

\begin{tabular}{|l|c|c|c|c|c|c|c|c|}
\hline \multirow{2}{*}{ Treatments } & \multicolumn{2}{|c|}{ Germination\% } & \multicolumn{2}{c|}{$\begin{array}{c}\text { Plant height } \\
\text { (cm) }\end{array}$} & $\begin{array}{c}\text { Number of leaves } \\
\text { / plant }\end{array}$ & $\begin{array}{c}\text { Neck diameter } \\
\text { (cm) }\end{array}$ \\
\cline { 2 - 9 } & M1V1 & M1V2 & M1V1 & M1V2 & M1V1 & M1V2 & M1V1 & M1V2 \\
\hline 1 Gy & $88.3 \mathrm{~B}$ & $95.5 \mathrm{BC}$ & $77.2 \mathrm{D}$ & $85.3 \mathrm{D}$ & $9.3 \mathrm{C}$ & $9.9 \mathrm{BC}$ & $1.0 \mathrm{E}$ & $1.5 \mathrm{CDE}$ \\
\hline $3 \mathrm{~Gy}$ & $62.7 \mathrm{G}$ & $94.3 \mathrm{CD}$ & $72.0 \mathrm{~F}$ & $75.6 \mathrm{E}$ & $9.4 \mathrm{E}$ & $9.5 \mathrm{C}$ & $0.78 \mathrm{~F}$ & $1.1 \mathrm{~F}$ \\
\hline $5 \mathrm{~Gy}$ & $46.3 \mathrm{I}$ & 93.3 & $57.7 \mathrm{G}$ & $67.8 \mathrm{~F}$ & $7.4 \mathrm{~F}$ & $9.3 \mathrm{C}$ & $0.7 \mathrm{FG}$ & $0.8 \mathrm{G}$ \\
\hline $10 \mathrm{~Gy}$ & $38.7 \mathrm{~J}$ & $89.8 \mathrm{~F}$ & $39.4 \mathrm{H}$ & $60.4 \mathrm{G}$ & $6.1 \mathrm{G}$ & $8.4 \mathrm{D}$ & $0.55 \mathrm{GH}$ & $0.8 \mathrm{G}$ \\
\hline $15 \mathrm{~Gy}$ & $4.7 \mathrm{~K}$ & $87.5 \mathrm{GH}$ & $18.8 \mathrm{I}$ & $46.9 \mathrm{H}$ & $4.7 \mathrm{H}$ & $6.4 \mathrm{E}$ & $0.42 \mathrm{H}$ & $0.8 \mathrm{G}$ \\
\hline $0.05 \% \mathrm{DES}$ & $85.2 \mathrm{C}$ & $95.8 \mathrm{~B}$ & $85.7 \mathrm{~B}$ & $78.6 \mathrm{E}$ & $9.4 \mathrm{BC}$ & $9.9 \mathrm{BC}$ & $1.6 \mathrm{~A}$ & $1.6 \mathrm{ABC}$ \\
\hline $0.1 \% \mathrm{DES}$ & $76.7 \mathrm{E}$ & $91.3 \mathrm{E}$ & $79.6 \mathrm{CD}$ & $84.9 \mathrm{D}$ & $9.1 \mathrm{C}$ & $1.0 \mathrm{BC}$ & $1.5 \mathrm{AB}$ & $1.7 \mathrm{AB}$ \\
\hline $0.2 \% \mathrm{DES}$ & $70.0 \mathrm{~F}$ & $88.2 \mathrm{G}$ & $72.9 \mathrm{EF}$ & $92.3 \mathrm{AB}$ & $8.6 \mathrm{de}$ & $1.0 \mathrm{BC}$ & $1.3 \mathrm{CD}$ & $1.4 \mathrm{DE}$ \\
\hline $0.3 \% \mathrm{DES}$ & $60.7 \mathrm{GH}$ & $81.5 \mathrm{I}$ & $70.3 \mathrm{~F}$ & $92.2 \mathrm{AB}$ & $8.3 \mathrm{E}$ & $11.0 \mathrm{~A}$ & $1.2 \mathrm{CD}$ & $1.8 \mathrm{~A}$ \\
\hline $0.05 \% \mathrm{DEA}$ & $87.0 \mathrm{BC}$ & $94.3 \mathrm{CD}$ & $87.0 \mathrm{AB}$ & $88.6 \mathrm{C}$ & $9.9 \mathrm{~A}$ & $10.4 \mathrm{AB}$ & $1.3 \mathrm{BC}$ & $1.3 \mathrm{EF}$ \\
\hline $0.1 \% \mathrm{DEA}$ & $81.3 \mathrm{D}$ & $91.3 \mathrm{E}$ & $81.6 \mathrm{C}$ & $90.9 \mathrm{BC}$ & $9.0 \mathrm{CD}$ & $10.8 \mathrm{~A}$ & $1.3 \mathrm{CD}$ & $1.4 \mathrm{E}$ \\
\hline \begin{tabular}{c}
$0.2 \% \mathrm{DEA}$ \\
\hline $0.3 \% \mathrm{G}$
\end{tabular} & $86.8 \mathrm{H}$ & $76.1 \mathrm{DE}$ & $92.1 \mathrm{AB}$ & $8.4 \mathrm{E}$ & $10.8 \mathrm{~A}$ & $1.3 \mathrm{CD}$ & 1.5 \\
\hline $0.3 \% \mathrm{DEA}$ & $59.0 \mathrm{H}$ & $81.7 \mathrm{I}$ & $69.2 \mathrm{~F}$ & $94.9 \mathrm{~A}$ & $7.5 \mathrm{~F}$ & $10.8 \mathrm{~A}$ & $1.1 \mathrm{DE}$ & $1.6 \mathrm{BCD}$ \\
\hline $\begin{array}{c}\text { Original cultivar } \\
\text { Balady }\end{array}$ & $97.0 \mathrm{~A}$ & $98.3 \mathrm{~A}$ & $89.8 \mathrm{~A}$ & $89.2 \mathrm{BC}$ & $9.8 \mathrm{AB}$ & $9.8 \mathrm{BC}$ & $1.2 \mathrm{CD}$ & $1.44 \mathrm{DE}$ \\
\hline
\end{tabular}

Means within each column followed by the same letter are not statistically different at 0.05 level (Duncan's range test). Gy: gamma-rays. 
Table 4. Effect of treatments by gamma-rays and di-ethyl sulphate (DES) and di(2-chloro ethyl) amine (DEA) on some vegetative parameters of garlic cultivar "Egaseed-1" in M1V1 in 2010/ 2011 and M1V2 in 2011/2012.

\begin{tabular}{|c|c|c|c|c|c|c|c|c|}
\hline \multirow{2}{*}{ Treatments } & \multicolumn{2}{|c|}{ Germination\% } & \multicolumn{2}{c|}{$\begin{array}{c}\text { Plant height } \\
\text { (cm) }\end{array}$} & \multicolumn{2}{c|}{$\begin{array}{c}\text { Number of leaves / } \\
\text { plant }\end{array}$} & $\begin{array}{c}\text { Neck diameter } \\
\text { (cm) }\end{array}$ \\
\cline { 2 - 9 } & M1V1 & M1V2 & M1V1 & M1V2 & M1V1 & M1V2 & M1V1 & M1V2 \\
\hline $1 \mathrm{~Gy}$ & $90.2 \mathrm{~B}$ & $96.5 \mathrm{~A}$ & $74.4 \mathrm{BC}$ & $82.9 \mathrm{C}$ & $9.8 \mathrm{~A}$ & $10.3 \mathrm{~A}$ & $1.0 \mathrm{D}$ & $1.5 \mathrm{CDE}$ \\
\hline $3 \mathrm{~Gy}$ & $82.2 \mathrm{C}$ & $94.3 \mathrm{~B}$ & $70.2 \mathrm{D}$ & $73.0 \mathrm{~F}$ & $9.0 \mathrm{~B}$ & $9.4 \mathrm{CDE}$ & $0.7 \mathrm{E}$ & $1.2 \mathrm{~F}$ \\
\hline $5 \mathrm{~Gy}$ & $69.2 \mathrm{G}$ & $93.5 \mathrm{BC}$ & $60.4 \mathrm{~F}$ & $62.5 \mathrm{G}$ & $7.8 \mathrm{C}$ & $9.6 \mathrm{BCD}$ & $0.7 \mathrm{E}$ & $0.8 \mathrm{G}$ \\
\hline $10 \mathrm{~Gy}$ & $38.2 \mathrm{H}$ & $92.0 \mathrm{D}$ & $34.8 \mathrm{H}$ & $54.9 \mathrm{H}$ & $5.9 \mathrm{EF}$ & $8.8 \mathrm{EFG}$ & $0.5 \mathrm{~F}$ & $0.8 \mathrm{G}$ \\
\hline $15 \mathrm{~Gy}$ & $2.2 \mathrm{I}$ & $90.0 \mathrm{E}$ & $18.9 \mathrm{I}$ & $45.4 \mathrm{I}$ & $5.3 \mathrm{~F}$ & $8.2 \mathrm{G}$ & $0.4 \mathrm{~F}$ & $0.8 \mathrm{G}$ \\
\hline $0.05 \% \mathrm{DES}$ & $91.7 \mathrm{~B}$ & $93.8 \mathrm{~B}$ & $77.3 \mathrm{~B}$ & $75.5 \mathrm{EF}$ & $7.9 \mathrm{C}$ & $8.3 \mathrm{G}$ & $1.6 \mathrm{~A}$ & $1.6 \mathrm{ABC}$ \\
\hline $0.1 \% \mathrm{DES}$ & $90.7 \mathrm{~B}$ & $90.5 \mathrm{E}$ & $70.9 \mathrm{CD}$ & $77.5 \mathrm{DE}$ & $7.6 \mathrm{CD}$ & $8.7 \mathrm{FG}$ & $1.5 \mathrm{~A}$ & $1.7 \mathrm{AB}$ \\
\hline $0.2 \% \mathrm{DES}$ & $79.7 \mathrm{D}$ & $88.5 \mathrm{FG}$ & $65.2 \mathrm{E}$ & $80.8 \mathrm{CD}$ & $7.5 \mathrm{CD}$ & $9.0 \mathrm{DEF}$ & $1.3 \mathrm{~B}$ & $1.4 \mathrm{DE}$ \\
\hline $0.3 \% \mathrm{DES}$ & $72.0 \mathrm{~F}$ & $80.0 \mathrm{H}$ & $63.1 \mathrm{EF}$ & $80.9 \mathrm{CD}$ & $8.0 \mathrm{C}$ & $9.0 \mathrm{DEF}$ & $1.2 \mathrm{BC}$ & $1.8 \mathrm{~A}$ \\
\hline $0.05 \% \mathrm{DEA}$ & $90.3 \mathrm{~B}$ & $92.3 \mathrm{CD}$ & $85.2 \mathrm{~A}$ & $82.9 \mathrm{C}$ & $8.8 \mathrm{~B}$ & $9.2 \mathrm{DEF}$ & $1.3 \mathrm{~B}$ & $1.3 \mathrm{EF}$ \\
\hline $0.1 \% \mathrm{DEA}$ & $82.0 \mathrm{C}$ & $89.8 \mathrm{EF}$ & $54.1 \mathrm{G}$ & $88.3 \mathrm{~B}$ & $8.1 \mathrm{C}$ & $9.4 \mathrm{CDE}$ & $1.3 \mathrm{~B}$ & $1.4 \mathrm{DE}$ \\
\hline $0.2 \% \mathrm{DEA}$ & $76.3 \mathrm{E}$ & $87.2 \mathrm{G}$ & $74.4 \mathrm{BC}$ & $96.9 \mathrm{~A}$ & $7.1 \mathrm{D}$ & $9.6 \mathrm{BCD}$ & $1.3 \mathrm{~B}$ & 1.5 \\
\hline $0.3 \% \mathrm{DEA}$ & $73.5 \mathrm{~F}$ & $78.3 \mathrm{I}$ & $70.3 \mathrm{D}$ & $97.9 \mathrm{~A}$ & $6.0 \mathrm{E}$ & $9.9 \mathrm{ABC}$ & $1.1 \mathrm{CD}$ & $1.6 \mathrm{ABC}$ \\
\hline $\begin{array}{c}\text { Original cultivar } \\
\text { Eggaseed }-1\end{array}$ & $97.7 \mathrm{~A}$ & $97.7 \mathrm{~A}$ & $83.7 \mathrm{~A}$ & $83.6 \mathrm{C}$ & $9.9 \mathrm{~A}$ & $10.2 \mathrm{AB}$ & $1.2 \mathrm{BC}$ & $1.4 \mathrm{DE}$ \\
\hline
\end{tabular}

Means within each column followed by the same letter are not statistically different at 0.05 level (Duncan's range test).

Gy: gamma-rays.

DES: di-ethyl sulphate

DEA: di(2-chloro ethyl) amine.

\section{Pigments content}

\subsection{Chlorophyll $a$ and $b$}

The data presented in (Tables 5 and 6 ) revealed that the range of chlorophyll a in the M1V1 was 885 to 912 in the Balady cultivar and 310 to 990 in mutants. The highest values were observed with plants which treated by $0.3 \%$ DES in the M1V1 in cv. Balady while in Eggaseed-1 population, the highest value was obtained in the M1V1 at $0.3 \%$ DEA treatment. Data (Tables 7 and 8 ) showed that there were significant differences among the different doses of gamma-rays, DES and DEA on chlorophyll $a$ and $b$. The doses of 10,15 Gy, $0.3 \%$ DES and $0.3 \%$ DEA gave the lowest values of chlorophyll a and b. in M1V1 of both cultivars. Generally it was found that gamma-rays gave higher effect on chlorophyll $a$ and $b$ than DES and DEA in M1V1 and M1V2 whereas, the high concentration of DES and DEA treatments gave the high values of chlorophyll $a$ and $b$ in two cultivars in M1V2.

\subsection{Carotenoids}

Carotenoids contents varied from 20 to 95 in M1V1 and from 50 to 104 in the M1V2 in Balady populations while, the range values were 10-100 in the M1V1 and 20-100 in the M1V2 in cv. Egaseed-1 respectively as shown in Tables 5 and 6 . Carotenoids contents of the two cultivars under study were decreased by using high doses of gamma-rays, DES and DEA doses increased in M1V1 (Tables 7 and 8). 
Hemada, A. A. et al.

Table 5. Range values of Chlorophyll A, Chlorophyll B and Carotenoids in garlic; cv. Balady in the first (M1V1) and second (M1V2) mutant-vegetative generations which were exposed to gammarays (gy), di-ethyl sulphate (DES) and di(2-chloro ethyl) amine (DEA).

\begin{tabular}{|l|c|c|c|c|c|c|}
\hline \multirow{2}{*}{ Treatments } & \multicolumn{2}{c|}{ Chlorophyll A } & \multicolumn{2}{c|}{ Chlorophyll B } & \multicolumn{2}{c|}{ Carotenoids } \\
\cline { 2 - 7 } & M1V1 & M1V2 & M1V1 & M1V2 & M1V1 & M1V2 \\
\hline 1 Gy & $550-629$ & $915-940$ & $310-410$ & $480-590$ & $50-60$ & $70-90$ \\
\hline 3 Gy & $471-521$ & $830-940$ & $220-240$ & $500-540$ & $45-50$ & $70-90$ \\
\hline 5 Gy & $340-410$ & $600-720$ & $130-185$ & $420-480$ & $30-40$ & $60-70$ \\
\hline 10 Gy & $310-360$ & $560-660$ & $140-160$ & $220-280$ & $29-35$ & $60-70$ \\
\hline 15 Gy & $260-300$ & $510-600$ & $110-150$ & $170-200$ & $20-30$ & $50-60$ \\
\hline $0.05 \%$ DES & $960-990$ & $870-950$ & $310-490$ & $310-360$ & $90-95$ & $60-70$ \\
\hline $0.1 \%$ DES & $936-990$ & $900-980$ & $285-445$ & $340-370$ & $70-95$ & $80-90$ \\
\hline $0.2 \%$ DES & $770-872$ & $980-1040$ & $270-430$ & $470-560$ & $60-70$ & $87-94$ \\
\hline $0.3 \%$ DES & $751-840$ & $1010-1084$ & $320-330$ & $480-580$ & $60-70$ & $95-100$ \\
\hline $0.05 \%$ DEA & $940-990$ & $660-710$ & $430-540$ & $150-230$ & $90-95$ & 77.84 \\
\hline $0.1 \%$ DEA & $860-920$ & $800-870$ & $360-370$ & $200-280$ & $80-90$ & $86-91$ \\
\hline $0.2 \%$ DEA & $660-710$ & $895-950$ & $151-232$ & $370-380$ & $60-70$ & $95-100$ \\
\hline $0.3 \%$ DEA & $620-700$ & $980-1030$ & $140-230$ & $530-540$ & $60-70$ & $97-104$ \\
\hline $\begin{array}{l}\text { Original } \\
\text { Balady }\end{array}$ & $885-972$ & $913-933$ & $440-580$ & $310-350$ & $70-90$ & $88-90$ \\
\hline $\begin{array}{l}\text { Polled data } \\
\text { treatments }\end{array}$ & & & & & \\
\hline
\end{tabular}

Gy: gamma-rays.

DES: di-ethyl sulphate.

DEA: di(2-chloro ethyl) amine.

Table 6. Range values of Chlorophyll A, Chlorophyll B and Carotenoids in garlic; cv. Egaseed-1 in the first (M1V1) and second (M1V2) mutant-vegetative generations which were exposed to gamma-rays (gy), di-ethyl sulphate (DES) and di(2-chloro ethyl) amine (DEA).

\begin{tabular}{|l|c|c|c|c|c|c|}
\hline \multirow{2}{*}{ Treatments } & \multicolumn{2}{|c|}{ Chlorophyll A } & \multicolumn{2}{c|}{ Chlorophyll B } & \multicolumn{2}{c|}{ Carotenoids } \\
\cline { 2 - 7 } & M1V1 & M1V2 & M1V1 & M1V2 & M1V1 & M1V2 \\
\hline 1 Gy & $800-880$ & $970-1030$ & $450-570$ & $370-390$ & $40-45$ & $78-93$ \\
\hline 5 Gy & $790-870$ & $910-950$ & $420-480$ & $340-380$ & $33-38$ & $77-83$ \\
\hline 10 Gy & $700-760$ & $830-900$ & $330-490$ & $280-370$ & $18-25$ & $70-75$ \\
\hline 15 Gy & $650-720$ & $820-850$ & $280-370$ & $280-300$ & $18-20$ & $60-70$ \\
\hline $0.05 \%$ DES & $420-520$ & $800-850$ & $270-300$ & $260-310$ & $10-12$ & $38-43$ \\
\hline $0.1 \%$ DES & $900-970$ & $800-820$ & $412-540$ & $120-150$ & $80-100$ & $83-85$ \\
\hline $0.2 \%$ DES & $750-770$ & $800-820$ & $180-310$ & $270-380$ & $77-82$ & $80-100$ \\
\hline $0.3 \%$ DES & $570-600-$ & $930-1140$ & $150-190$ & $470-550$ & $70-80$ & $83-95$ \\
\hline $0.05 \%$ DEA & $950-1005$ & $790-840$ & $390-530$ & $120-180$ & $60-70$ & $20-35$ \\
\hline $0.1 \%$ DEA & $897-920$ & $820-860$ & $445-460$ & $280-480$ & $44-57$ & $45-50$ \\
\hline $0.2 \%$ DEA & $810-835$ & $980-1050$ & $98-150$ & $340-370$ & $30-50$ & $25-70$ \\
\hline $0.3 \%$ DEA & $675-720$ & $1320-1370$ & $90-180$ & $460-480$ & $20-25$ & $60-70$ \\
\hline $\begin{array}{l}\text { Original } \\
\text { Egseed-1 }\end{array}$ & $760-940$ & $920-940$ & $490-510$ & $330-390$ & $85-88$ & $85-94$ \\
\hline Polled data & $420-1005$ & $790-1370$ & $90-570$ & $120-550$ & $10-100$ & $20-100$ \\
\hline
\end{tabular}

Gy: gamma-rays.

DES: di-ethyl sulphate. DEA: di(2-chloro ethyl) amine.

The results showed that significant differences among treated and control (orginal cultivars) in both cultivars. However, a highly significant 
decrease was found at 15 Gy in M1V1 and M1V2. On the other side, carotenoids contents were increased with increasing the concentration of DES and DEA in M1V2 generation. Use of $0.3 \%$ DES gave high values of carotenoids with non significant differences from $0.1 \%$ DES and $0.2 \%$ DES treatments in M1V2 of cv. Eggaseed-1, while in cv. Balady a high concentration of DEA gave the highest value of carotenoids with non significant differences from $0.2 \%$ DEA in M1V2.

Table 7. Effect of treatments with gamma-rays and di-ethyl sulphate (DES) and di(2-chloro ethyl) amine (DEA) on pigments contents of garlic cultivar "Balady" in M1V1 in 2010/ 2011 and M1V2 in 2011/2012 ( $\mathrm{mg} / \mathrm{gram}$ dry weight)

\begin{tabular}{|l|c|c|c|c|c|c|}
\hline \multirow{2}{*}{ Treatments } & \multicolumn{2}{|c|}{ Chlorophyll A } & \multicolumn{2}{c|}{ Chlorophyll B } & \multicolumn{2}{c|}{ Carotenoids } \\
\cline { 2 - 6 } & M1V1 & M1V2 & M1V1 & M1V2 & M1V1 & M1V2 \\
\hline 1 Gy & $589.7 \mathrm{~F}$ & $94.7 \mathrm{BC}$ & $360.3 \mathrm{BC}$ & $518.7 \mathrm{~A}$ & $57.0 \mathrm{D}$ & $82.7 \mathrm{C}$ \\
\hline $3 \mathrm{~Gy}$ & $496.0 \mathrm{G}$ & $884.3 \mathrm{C}$ & $227.0 \mathrm{D}$ & $521.0 \mathrm{~A}$ & $48.0 \mathrm{E}$ & $79.7 \mathrm{C}$ \\
\hline $5 \mathrm{~Gy}$ & $372.3 \mathrm{H}$ & $651.3 \mathrm{E}$ & $159.3 \mathrm{E}$ & $453.0 \mathrm{~B}$ & $35.7 \mathrm{~F}$ & $63.3 \mathrm{D}$ \\
\hline $10 \mathrm{~Gy}$ & $334.7 \mathrm{H}$ & $608.0 \mathrm{~F}$ & $152.0 \mathrm{E}$ & $255.0 \mathrm{E}$ & $32.0 \mathrm{~F}$ & $63.0 \mathrm{D}$ \\
\hline $15 \mathrm{~Gy}$ & $270.7 \mathrm{I}$ & $557.7 \mathrm{G}$ & $133.7 \mathrm{E}$ & $189.7 \mathrm{~F}$ & $26.3 \mathrm{G}$ & $54.0 \mathrm{E}$ \\
\hline $0.05 \% \mathrm{DES}$ & $982.3 \mathrm{~A}$ & $911.7 \mathrm{BC}$ & $405.0 \mathrm{~B}$ & $335.7 \mathrm{D}$ & $93.3 \mathrm{~A}$ & $66.0 \mathrm{D}$ \\
\hline $0.1 \% \mathrm{DES}$ & $898.7 \mathrm{C}$ & $941.0 \mathrm{~B}$ & $365.3 \mathrm{BC}$ & $352.7 \mathrm{CD}$ & $84.0 \mathrm{~B}$ & $88.3 \mathrm{~B}$ \\
\hline $0.2 \% \mathrm{DES}$ & $821.0 \mathrm{D}$ & $1013.0 \mathrm{~A}$ & $355.0 \mathrm{BC}$ & $514.0 \mathrm{~A}$ & $64.7 \mathrm{C}$ & $91.7 \mathrm{~B}$ \\
\hline $0.3 \% \mathrm{DES}$ & $797.3 \mathrm{D}$ & $1036.0 \mathrm{~A}$ & $332.7 \mathrm{C}$ & $531.0 \mathrm{~A}$ & $62.7 \mathrm{C}$ & $98.0 \mathrm{~A}$ \\
\hline $0.05 \% \mathrm{DEA}$ & $970.7 \mathrm{AB}$ & $682.0 \mathrm{E}$ & $490.0 \mathrm{~A}$ & $192.0 \mathrm{~F}$ & $94.0 \mathrm{~A}$ & $81.0 \mathrm{C}$ \\
\hline $0.1 \% \mathrm{DEA}$ & $892.7 \mathrm{C}$ & $771.0 \mathrm{D}$ & $364.7 \mathrm{BC}$ & $244.3 \mathrm{E}$ & $86.3 \mathrm{~B}$ & $89.3 \mathrm{~B}$ \\
\hline $0.2 \% \mathrm{DEA}$ & $682.0 \mathrm{E}$ & $921.3 \mathrm{BC}$ & $192.3 \mathrm{DE}$ & $376.3 \mathrm{C}$ & $66.0 \mathrm{C}$ & $97.7 \mathrm{~A}$ \\
\hline $0.3 \% \mathrm{DEA}$ & $656.3 \mathrm{E}$ & $1008.0 \mathrm{~A}$ & $185.7 \mathrm{DE}$ & $535.7 \mathrm{~A}$ & $63.7 \mathrm{C}$ & $99.7 \mathrm{~A}$ \\
\hline Original cultivar & $924.0 \mathrm{BC}$ & $918.0 \mathrm{BC}$ & $512.3 \mathrm{~A}$ & $328.7 \mathrm{D}$ & $83.0 \mathrm{~B}$ & $88.7 \mathrm{~B}$ \\
\hline Balady & & & & & & \\
\hline
\end{tabular}

Means within each column followed by the same letter are not statistically different at 0.05 level (Duncan's range test).

Gy: gamma-rays

DES: di-ethyl sulphate. DEA: di(2-chloro ethyl) amine

Table 8. Effect of treatments with gamma-rays and di-ethyl sulphate (DES) and di(2-chloro ethyl) amine (DEA) on pigments contents of garlic cultivar "Egaseed-1" in M1V1 in 2010/ 2011 and M1V2 in 2011/2012 (mg/gram dry weight)

\begin{tabular}{|l|c|c|c|c|c|c|}
\hline \multirow{2}{*}{ Treatments } & \multicolumn{2}{|c|}{ Chlorophyll A } & \multicolumn{2}{c|}{ Chlorophyl B } & \multicolumn{2}{c|}{ Carotenoids } \\
\cline { 2 - 6 } & M1V1 & M1V2 & M1V1 & M1V2 & M1V1 & M1V2 \\
\hline $1 \mathrm{~Gy}$ & $840.7 \mathrm{C}$ & $362.0 \mathrm{~B}$ & $511.0 \mathrm{~A}$ & $362.0 \mathrm{~B}$ & $43.3 \mathrm{G}$ & $86.3 \mathrm{AB}$ \\
\hline $3 \mathrm{~Gy}$ & $579.7 \mathrm{G}$ & $353.0 \mathrm{~B}$ & $451.0 \mathrm{BC}$ & $353.0 \mathrm{~B}$ & $35.7 \mathrm{H}$ & $80.0 \mathrm{BC}$ \\
\hline $5 \mathrm{~Gy}$ & $730.7 \mathrm{DE}$ & $323.0 \mathrm{BC}$ & $428.0 \mathrm{C}$ & $323.0 \mathrm{BC}$ & $20.0 \mathrm{I}$ & $73.0 \mathrm{CD}$ \\
\hline $10 \mathrm{~Gy}$ & $663.0 \mathrm{EF}$ & $286.0 \mathrm{C}$ & $323.0 \mathrm{D}$ & $286.0 \mathrm{C}$ & $19.0 \mathrm{I}$ & $63.0 \mathrm{E}$ \\
\hline $15 \mathrm{~Gy}$ & $475.0 \mathrm{H}$ & $280.0 \mathrm{C}$ & $292.0 \mathrm{DE}$ & $280.0 \mathrm{C}$ & $11.0 \mathrm{~J}$ & $41.0 \mathrm{G}$ \\
\hline $0.05 \% \mathrm{DES}$ & $943.7 \mathrm{AB}$ & $143.0 \mathrm{D}$ & $475.0 \mathrm{ABC}$ & $143.0 \mathrm{D}$ & $89.0 \mathrm{~A}$ & $75.0 \mathrm{CD}$ \\
\hline $0.1 \% \mathrm{DES}$ & $928.3 \mathrm{AB}$ & $282.0 \mathrm{C}$ & $269.0 \mathrm{DE}$ & $282.0 \mathrm{C}$ & $82.7 \mathrm{BC}$ & $84.0 \mathrm{AB}$ \\
\hline $0.2 \%$ DES & $764.3 \mathrm{D}$ & $334.0 \mathrm{BC}$ & $242.0 \mathrm{E}$ & $334.0 \mathrm{BC}$ & $80.3 \mathrm{C}$ & $85.0 \mathrm{AB}$ \\
\hline $0.3 \% \mathrm{DES}$ & $583.7 \mathrm{G}$ & $486.0 \mathrm{~A}$ & $163.0 \mathrm{~F}$ & $486.0 \mathrm{~A}$ & $72.7 \mathrm{D}$ & $91.0 \mathrm{~A}$ \\
\hline $0.05 \% \mathrm{DEA}$ & $984.0 \mathrm{~A}$ & $147.0 \mathrm{D}$ & $460.0 \mathrm{ABC}$ & $147.0 \mathrm{D}$ & $64.7 \mathrm{E}$ & $31.0 \mathrm{H}$ \\
\hline $0.1 \% \mathrm{DEA}$ & $909.7 \mathrm{ABC}$ & $352.0 \mathrm{~B}$ & $456.0 \mathrm{ABC}$ & $352.0 \mathrm{~B}$ & $50.3 \mathrm{~F}$ & $46.3 \mathrm{FG}$ \\
\hline $0.2 \%$ DEA & $622.0 \mathrm{DE}$ & $352.0 \mathrm{~B}$ & $155.0 \mathrm{~F}$ & $352.0 \mathrm{~B}$ & $45.7 \mathrm{FG}$ & $52.7 \mathrm{~F}$ \\
\hline $0.3 \%$ DEA & $689.0 \mathrm{DE}$ & $469.0 \mathrm{~A}$ & $128.0 \mathrm{~F}$ & $469.0 \mathrm{~A}$ & $21.0 \mathrm{I}$ & $\mathbf{6 8 . 3} \mathrm{DE}$ \\
\hline Original cultivar & $873.3 \mathrm{BC}$ & $356.0 \mathrm{~B}$ & $501.0 \mathrm{AB}$ & $356.0 \mathrm{~B}$ & $87.0 \mathrm{AB}$ & $\mathbf{8 9 . 0} \mathrm{A}$ \\
\hline Egaseed-1 & & & & & & \\
\hline
\end{tabular}

Means within each column followed by the same letter are not statistically different at 0.05 level (Duncan's range test).

Gy: gamma-rays. DES: di-ethyl sulphate. DEA: di(2-chloro ethyl) amine 
Hemada, A. A. et al.

\section{Yield and its component}

Mutants exhibited a wider range of fresh yield in cvs. Balady and Egaseed-1 (Tables 9 and 10). The values for cv. Balady were ranged from 0.42 to 10.63 tons in the M1V1 and from 6.17 to 12.0 tons in the M1V2 where these values in cv. Egaseed-1 ranged from 0.46 to 11.9 and from 5.8 to 12.5 tons in the M1V1 and M1V2, respectively. Data shown in (Table 11 and 12) indicated that fresh yield in cultivars Balady and Eggaseed-1was decreased as a result of exposure to 10 and $15 \mathrm{~Gy}$ of gamma-rays in M1V1, while highly significant increases were observed at $1 \mathrm{~Gy}$ and low doses of the used chemical mutagens compared to the original cultivars in M1V2. Fresh yield in cultivar Balady and Eggaseed-1 were promoted by using high concentrations of DES and DEA. These treatments gave the highest values in Balady and Eggaseed-1 in M1V2. To improve the crop productivity by mutation breeding, it is very important to determine the suitable mutagen dose (Agrawal et al. 2003 and Joshi et al., 2011).

\subsection{Cured yield ton / fed}

Cured yield ranged from 0.19 to 4.78 tons in the M1V1and from 3.10 to 6.00 tons in the M1V2 for Balady population (Table 9). In Eggaseed-1 population, the values of this trait ranged 0.27-6.8 tons and 3.5-7.5 ton in the M1V1and M1V2, respectively (Table 10). Data presented in tables 11 and 12 indicated that there were significant differences among the different doses of gamma-rays, DES and DEA on cured yield trait. The doses of 10, 15 Gy, $0.3 \%$ DES and $0.3 \%$ DEA produced the lowest values of cured yield in the M1V1 of the two studied cultivars. Generally, it was found that gamma-rays gave a higher cured y Bulb weight ranged from 7 to $86 \mathrm{~g}$ in the M1V1and from 16 to $84 \mathrm{~g}$ in the M1V2 for Balady population (Table 9 and 10). In Eggaseed-1 population, the values of bulb weight ranged from 10-95 $\mathrm{g}$ and 31-127 $\mathrm{g}$ in the M1V1and M1V2, respectively (Table 10). yield than DES and DEA in M1V1and M1V2 for both populations of cvs. Balady and Egaseed1.However, the highest cured yield obtained by using lower dose 1 of gamma-rays (Gy) in the M1V2 for Balady and Eggaseed-1 populations. The highest concentration $(0.3 \%)$ of DES and DEA promoted the values of cured yield in both cultivars in M1V2.

\subsection{Yield components}

The range for bulb diameter in M1V2 indicated that in mutants there was a shift in both directions in comparison to parents (Tables 9 and 10), the highest values were recorded with Eggaseed-1 at $0.2 \%$ DEA. Data presented in (Tables 11 and 12) showed that there were significant differences among the different doses of gamma-rays on cured bulb diameter. The dose of 10 Gy and 15 Gy gave the lowest values in cvs. Balady and Eggaseed-1 in the M1V1and M1V2. Generally, it was found that gamma-rays gave higher effect on bulb diameter than DES and DEA treatments in both cultivars as well as in the M1V1and M1V2 generations. On the other hand, increasing bulb diameter was observed by using low doses of gamma-radiation in both cultivars. These results were in agreement with Shalaby et al: (1983 a and b) who found that in the M2 generation, gamma radiation and ethylmethan sulfonate (EMS) treatments increased the variability of garlic bulb weight. 


\subsubsection{Cured bulb weight}

Bulb weight ranged from 7 to $86 \mathrm{~g}$ in the M1V1and from 16 to $84 \mathrm{~g}$ in the M1V2 for Balady population (Table 9 10). In Eggaseed-1 population, the values of bulb weight ranged from 10-95 $\mathrm{g}$ and 31-127 $\mathrm{g}$ in the M1V1and M1V2, respectively (Table 10).

Data in (Tables 11 and 12) indicated that cured bulb weight in cultivars Balady and Eggaseed-1was decreased as a result of exposure to 10 and 15 of gamma-rays (Gy) in M1V1. The highly significant increase was observed at 1 Gy compared to the original cultivars in the M1V2. Cured bulb weight in cvs Balady and Eggaseed-1was increased as a result of exposure to high concentration of DES and DEA in M1V1 whereas $0.3 \%$ DEA treatment gave the highest values in the M1V2 of both cultivars. These results agreed with those obtained by Shalaby et al. (1983 a and b) who found that in the M2 generation, gamma radiation and EMS treatments increased the variability of garlic bulb weight.

\subsubsection{Clove weight $(\mathrm{g})$ :}

Clove weight values were smaller in cv. Balady than in cv. Egaseed-1 (Tables 9 and 10). The range values over all treatments in Balady was 0.51.9 and $1.1-3.0 \mathrm{~g}$ in the M1V1 and M1V2, respectively. On the other side, these values in cv. Egaseed-1 were 1.2 to 4.5 and 3.2 to $7.0 \mathrm{~cm}$ in M1V1 and M1V2, respectively. Data shown in (Tables 11 and 12) indicated that clove weight in cvs. Balady and Eggaseed-1 was decreased as a results of using 10 and 15 Gy of gamma-rays, while significant increase was observed at 1 Gy compared to the original cultivars in both generations. The concentration of $0.05 \%$ DES in the M1V1 of both cultivars gave the largest values of clove weight, while using $0.3 \%$ DEA gave the largest values of clove weight $(\mathrm{g})$ in the M1V2. These results in agreement with those reported by Shalaby et al., (1983 a and b) who found increasing in the clove weight trait in the garlic plant of M2 generation which resulted from gamma and EMS treatments.

\section{4-Number of cloves/bulb}

Number of cloves ranged from 10 to 41 in the M1V1and from 13 to 41 in the M1V2 for Balady population (Table 9). In Eggaseed-1 population, the values of this trait ranged from 6-27 and 7-29 in the M1V1and M1V2, respectively (Table 10). Data presented in Tables 11 and 12 showed that, there were highly significant differences among the treatment means in M1V1and M1V2. Number of cloves was decreased in the two cultivars with increasing the doses of gamma-rays, DES and DEA. The reduction was differed from M1V1 to M1V2 in both cultivars. In cultivars Balady and Eggaseed-1, considerable reductions were occurred when doses of $10 \mathrm{~Gy}$ and above were used in the M1V1 and M1V2 but the M1V2 gave the highest numbers of cloves/bulb. In the cv. Balady, a significant increase was found at $0.1 \%$ DES treatment in M1V2. While, in the cv. Eggaseed-1 a significant increase was found at $0.05 \%$ DES in the M1V2. These results gives a window of opportunity to manipulate the selection process in such a way that the desired number of cloves per bulb is attained (Metwally and El-Denary, 2003).

In the present investigation lower doses of gamma-rays and higher concentrations of the two chemical mutagens (DES and DEA) showed higher 
Hemada, A. A. et al.

effectiveness values. Similar results were found by Shalaby et al.(1983 a and b) and Kumar and Tiwari (1998). However, a wide range of variable mutations was observed in M1V2 generation of garlic treated with various concentrations of DES, DEA and gamma-rays. Thus, identifying plant characteristics which have quality roles in developing new garlic materials should be done. In this regard estimates of simple correlation coefficients is a straight way for getting selection index, which will be used in advanced generations (Singh et al., 2011).

Table 9. Range values of some yield characteristics in garlic; cv. Balady in the first (M1V1) and second (M1V2) mutant-vegetative generations which were exposed to gamma-rays (gy), di-ethyl sulphate (DES) and di(2-chloro ethyl) amine (DEA).

\begin{tabular}{|c|c|c|c|c|c|c|c|c|c|c|c|c|}
\hline \multirow[t]{2}{*}{ Treatments } & \multicolumn{2}{|c|}{$\begin{array}{c}\text { Cured bulb } \\
\text { diameter } \mathbf{c m} \text { ) }\end{array}$} & \multicolumn{2}{|c|}{$\begin{array}{l}\text { Cured bulb } \\
\text { Weight (g) }\end{array}$} & \multicolumn{2}{|c|}{$\begin{array}{l}\text { Clove weight } \\
\text { (g) }\end{array}$} & \multicolumn{2}{|c|}{$\begin{array}{c}\text { Number of } \\
\text { cloves / plant }\end{array}$} & \multicolumn{2}{|c|}{$\begin{array}{l}\text { Fresh yield } \\
\text { Ton /fed. }\end{array}$} & \multicolumn{2}{|c|}{$\begin{array}{c}\text { Cured yield } \\
\text { Ton /fed. }\end{array}$} \\
\hline & M1V1 & M1V2 & M1V1' & M1V2 & M1V1 & M1V2 & M1V1 & M1V2 & M1V1 & M1V2 & M1V1' & M1V2 \\
\hline Gy & $\begin{array}{c}4.0- \\
4.8\end{array}$ & $\begin{array}{l}5.0- \\
6.2\end{array}$ & $47-53$ & $47-65$ & $\begin{array}{l}1.6- \\
1.8\end{array}$ & $\begin{array}{l}2.1- \\
2.5\end{array}$ & $25-31$ & $16-34$ & $\begin{array}{l}5.26- \\
7.92\end{array}$ & $\begin{array}{l}10.40- \\
11.43\end{array}$ & \begin{tabular}{|l|}
$2.37-$ \\
3.57
\end{tabular} & $\begin{array}{l}5.20- \\
5.71\end{array}$ \\
\hline $3 \mathrm{~Gy}$ & $\begin{array}{l}3.0- \\
4.4\end{array}$ & $\begin{array}{l}4.7- \\
5.6\end{array}$ & $34-45$ & $46-54$ & $\begin{array}{l}1.3- \\
1.5\end{array}$ & $\begin{array}{l}2.0- \\
2.4\end{array}$ & $24-29$ & $20-25$ & $\begin{array}{l}5.26- \\
5.64\end{array}$ & $\begin{array}{l}10.63- \\
10.74\end{array}$ & \begin{tabular}{|l|}
$2.30-$ \\
2.54
\end{tabular} & $\begin{array}{l}5.31- \\
5.37\end{array}$ \\
\hline 5 Gy & $\begin{array}{l}3.6- \\
4.2\end{array}$ & $\begin{array}{l}4.5- \\
5.3\end{array}$ & $7-26$ & $37-43$ & $\begin{array}{l}0.8- \\
1.2\end{array}$ & $\begin{array}{l}1.8- \\
2.0\end{array}$ & $9-22$ & $15-25$ & $\begin{array}{l}3.05- \\
4.11\end{array}$ & $\begin{array}{l}8.23- \\
9.70\end{array}$ & & $\begin{array}{l}4.10- \\
4.86\end{array}$ \\
\hline 10 Gy & $\begin{array}{l}2.0- \\
3.4\end{array}$ & $\begin{array}{l}3.5- \\
5.1\end{array}$ & -19 & $24-31$ & $\begin{array}{l}0.7- \\
0.9\end{array}$ & $\begin{array}{l}1.5- \\
1.7\end{array}$ & 17-19 & $15-17$ & $\begin{array}{l}0.57- \\
0.72\end{array}$ & $\begin{array}{l}7.31- \\
7.77\end{array}$ & & $\begin{array}{l}3.66- \\
3.89\end{array}$ \\
\hline $15 \mathrm{~Gy}$ & $\begin{array}{l}1.9- \\
2.8\end{array}$ & $\begin{array}{l}3.3- \\
5.0\end{array}$ & $7.0-10$ & $16-20$ & $\begin{array}{l}0.5- \\
0.7\end{array}$ & $\begin{array}{l}1.1- \\
1.3\end{array}$ & $10-13$ & $13-15$ & $\begin{array}{l}0.42- \\
0.48\end{array}$ & $\begin{array}{l}6.17- \\
6.86\end{array}$ & \begin{tabular}{|l|}
$0.19-$ \\
0.22
\end{tabular} & $\begin{array}{l}3.10- \\
3.43\end{array}$ \\
\hline $\begin{array}{l}0.05 \\
\text { DES }\end{array}$ & $\begin{array}{l}4.5- \\
5.6\end{array}$ & $\begin{array}{l}4.3- \\
6.0\end{array}$ & 74 & $54-70$ & $\begin{array}{l}1.8- \\
2.0\end{array}$ & $\begin{array}{l}2.1- \\
2.6\end{array}$ & $31-41$ & $20-31$ & $\begin{array}{l}5.03- \\
5.64\end{array}$ & $\begin{array}{l}7.77- \\
9.19\end{array}$ & \begin{tabular}{|l|}
$2.26-$ \\
2.54
\end{tabular} & $\begin{array}{l}3.89- \\
4.57\end{array}$ \\
\hline $0.1 \%$ DES & $\begin{array}{l}4.5- \\
5.6\end{array}$ & $\begin{array}{l}4.2- \\
6.7\end{array}$ & $7-70$ & 64-69 & $\begin{array}{l}1.6- \\
1.9\end{array}$ & $\begin{array}{c}2.5- \\
2.8\end{array}$ & 33-38 & $22-28$ & $\begin{array}{l}4.65- \\
5.48\end{array}$ & $\begin{array}{l}6.00- \\
9.37\end{array}$ & \begin{tabular}{|l|}
$2.10-$ \\
2.47
\end{tabular} & $\begin{array}{l}4.00- \\
4.69\end{array}$ \\
\hline $0.2 \%$ DES & $\begin{array}{l}4.3- \\
5.5\end{array}$ & $\begin{array}{l}5.2- \\
6.5\end{array}$ & $3-55$ & $6-68$ & $\begin{array}{l}1.4- \\
1.6\end{array}$ & $\begin{array}{l}2.6- \\
2.9\end{array}$ & $3-36$ & $18-24$ & $\begin{array}{l}4.04- \\
4.88\end{array}$ & $\begin{array}{l}9.37- \\
10.74\end{array}$ & \begin{tabular}{|l|}
$1.82-$ \\
2.10
\end{tabular} & $\begin{array}{l}4.86- \\
5.37\end{array}$ \\
\hline $0.3 \%$ DES & $\begin{array}{l}3.2- \\
4.8\end{array}$ & $\begin{array}{l}4.9- \\
6.5\end{array}$ & $27-40$ & $1-74$ & $\begin{array}{l}1.0- \\
1.4\end{array}$ & $\begin{array}{l}2.7- \\
2.9\end{array}$ & $22-30$ & $17-22$ & $\begin{array}{l}3.96- \\
4.72\end{array}$ & $\begin{array}{l}9.70- \\
10.74\end{array}$ & \begin{tabular}{|l|}
$1.78-$ \\
2.20
\end{tabular} & $\begin{array}{l}4.86- \\
5.37\end{array}$ \\
\hline $\begin{array}{l}0.05 \\
D E A\end{array}$ & $\begin{array}{l}3.4- \\
5.1\end{array}$ & $\begin{array}{l}3.9- \\
5.2\end{array}$ & 61-75 & $54-73$ & $\begin{array}{l}1.7- \\
1.9\end{array}$ & $\begin{array}{l}2.1- \\
2.5\end{array}$ & $30-40$ & $24-28$ & $\begin{array}{c}3.96- \\
4.42\end{array}$ & $\begin{array}{l}7.20- \\
7.77\end{array}$ & $\begin{array}{l}1.71- \\
1.99\end{array}$ & $\begin{array}{l}3.60- \\
3.89\end{array}$ \\
\hline $0.1 \%$ DEA & $\begin{array}{l}3.0- \\
4.7\end{array}$ & $\begin{array}{l}3.8- \\
5.8\end{array}$ & $36-46$ & $57-70$ & $\begin{array}{l}1.5- \\
1.7\end{array}$ & $\begin{array}{l}2.2- \\
2.6\end{array}$ & $21-29$ & $24-28$ & $\begin{array}{c}3.66- \\
4.10\end{array}$ & $\begin{array}{l}7.54- \\
8.69\end{array}$ & $\begin{array}{c}1.65- \\
1.85\end{array}$ & $\begin{array}{l}3.77- \\
4.34\end{array}$ \\
\hline $0.2 \%$ DEA & $\begin{array}{l}3.1- \\
4.3\end{array}$ & $\begin{array}{c}4.1- \\
5.3\end{array}$ & $31-38$ & $63-71$ & $\begin{array}{l}1.3- \\
1.5\end{array}$ & $\begin{array}{l}2.5- \\
2.8\end{array}$ & $20-26$ & $21-28$ & $\begin{array}{c}3.50- \\
3.73\end{array}$ & $\begin{array}{c}7.89- \\
8.69\end{array}$ & $\begin{array}{c}1.58- \\
1.68\end{array}$ & $\begin{array}{c}3.94- \\
4.39\end{array}$ \\
\hline $0.3 \%$ DEA & $\begin{array}{c}3.0- \\
3.9\end{array}$ & $\begin{array}{c}4.0- \\
5.8 \\
\end{array}$ & $24-29$ & 67-72 & $\begin{array}{c}0.9- \\
1.2 \\
\end{array}$ & $\begin{array}{c}2.8- \\
3.0\end{array}$ & 19-33 & 16-21 & $\begin{array}{l}3.05- \\
3.58\end{array}$ & $\begin{array}{l}10.37- \\
12.00\end{array}$ & $\begin{array}{c}1.37- \\
1.61\end{array}$ & $\begin{array}{l}5.19- \\
6.00\end{array}$ \\
\hline $\begin{array}{l}\text { Original } \\
\text { cultivar } \\
\text { Balady }\end{array}$ & $\begin{array}{l}4.5- \\
6.3\end{array}$ & $\begin{array}{l}4.3- \\
5.6\end{array}$ & $79-86$ & $81-84$ & $\begin{array}{l}1.6- \\
1.8\end{array}$ & $\begin{array}{c}2.1- \\
2.5\end{array}$ & $28-38$ & $29-41$ & $\begin{array}{c}9.71- \\
10.63\end{array}$ & $\begin{array}{l}9.94- \\
10.63\end{array}$ & $\begin{array}{c}4.37- \\
4.78\end{array}$ & $\begin{array}{c}4.97- \\
5.31\end{array}$ \\
\hline Polled data & $\begin{array}{l}1.9- \\
6.3\end{array}$ & $\begin{array}{l}3.3- \\
6.7\end{array}$ & $7-8.7$ & $16-84$ & $\begin{array}{c}0.5- \\
1.9\end{array}$ & $\begin{array}{l}1.1- \\
3.0\end{array}$ & $10-41$ & $13-41$ & $\begin{array}{c}0.42- \\
10.63\end{array}$ & $\begin{array}{l}6.17- \\
12.0\end{array}$ & \begin{tabular}{|c|}
$0.19-$ \\
4.78
\end{tabular} & $\begin{array}{l}3.10- \\
6.00\end{array}$ \\
\hline
\end{tabular}

Gy: gamma-rays

DES: di-ethyl sulphate.

DEA: di(2-chloro ethyl) amine 
Table 10. Range values of some yield characteristics in garlic; cv. Egaseed-1 in the first (M1V1) and second (M1V2) mutantvegetative generations which were exposed to gamma-rays (gy), di-ethyl sulphate (DES) and di(2-chloro ethyl) amine (DEA).

\begin{tabular}{|c|c|c|c|c|c|c|c|c|c|c|c|c|}
\hline \multirow[t]{2}{*}{ Treatments } & \multicolumn{2}{|c|}{$\begin{array}{c}\text { Cured bulb } \\
\text { diameter } \mathrm{cm} \text { ) }\end{array}$} & \multicolumn{2}{|c|}{$\begin{array}{l}\text { Cured bulb } \\
\text { Weight (g) }\end{array}$} & \multicolumn{2}{|c|}{$\begin{array}{c}\text { Clove } \\
\text { weight } \\
\text { (g) }\end{array}$} & \multicolumn{2}{|c|}{$\begin{array}{c}\text { Number of } \\
\text { cloves / plant }\end{array}$} & \multicolumn{2}{|c|}{$\begin{array}{l}\text { Fresh yield } \\
\text { ton /fed. }\end{array}$} & \multicolumn{2}{|c|}{$\begin{array}{l}\text { Cured yield } \\
\text { Ton /fed. }\end{array}$} \\
\hline & M1V1 & M1V2 & M1V1' & M1V2 & M1V1 & M1V2 & M1V1 & M1V2 & M1V1 & M1V2 & M1V1 & M1V2 \\
\hline I Gy & $\begin{array}{c}3.0- \\
4.1\end{array}$ & $\begin{array}{c}4.8- \\
6.5 \\
\end{array}$ & $61-66$ & $81-96$ & $\begin{array}{l}3.5- \\
3.7\end{array}$ & $\begin{array}{c}4.7- \\
4.9 \\
\end{array}$ & $14-22$ & $14-20$ & $\begin{array}{l}7.2- \\
8.7\end{array}$ & \begin{tabular}{|c|}
$11.5-$ \\
12.2 \\
\end{tabular} & $\begin{array}{l}4.3- \\
5.3\end{array}$ & $\begin{array}{l}6.9- \\
7.3\end{array}$ \\
\hline $3 \mathrm{~Gy}$ & $\begin{array}{l}3.0- \\
3.9\end{array}$ & $\begin{array}{c}4.3- \\
5.9\end{array}$ & $37-40$ & $62-70$ & $\begin{array}{l}2.3- \\
2.5\end{array}$ & $\begin{array}{l}3.9- \\
4.1\end{array}$ & $13-16$ & 13-19 & $\begin{array}{l}5.1- \\
6.1\end{array}$ & $\begin{array}{l}8.7- \\
8.8\end{array}$ & $\begin{array}{l}3.0- \\
3.7\end{array}$ & $\begin{array}{l}5.2- \\
5.4\end{array}$ \\
\hline 5 Gy & $\begin{array}{c}3.0- \\
4.0\end{array}$ & $\begin{array}{c}4.5- \\
5.8\end{array}$ & $31-36$ & $62-71$ & $\begin{array}{l}2.1- \\
2.3\end{array}$ & $\begin{array}{c}3.8- \\
4.0\end{array}$ & $12-14$ & 13-19 & $\begin{array}{c}4.2- \\
5.7\end{array}$ & $\begin{array}{l}7.7- \\
8.3\end{array}$ & $\begin{array}{l}2.4- \\
3.0\end{array}$ & $\begin{array}{c}4.6- \\
5.0\end{array}$ \\
\hline $10 \mathrm{~Gy}$ & $\begin{array}{l}2.5- \\
3.4\end{array}$ & $\begin{array}{l}3.3- \\
5.2\end{array}$ & $19-24$ & $47-59$ & $\begin{array}{l}1.6- \\
1.8\end{array}$ & $\begin{array}{l}3.7- \\
3.9\end{array}$ & $8.0-12$ & 8.0-17 & \begin{tabular}{|l|}
$0.70-$ \\
0.96
\end{tabular} & $\begin{array}{l}6.6- \\
7.1\end{array}$ & $\begin{array}{c}0.4- \\
0.6\end{array}$ & $\begin{array}{c}3.9- \\
4.4\end{array}$ \\
\hline 15 Gy & $\begin{array}{l}1.8- \\
2.9\end{array}$ & $\begin{array}{c}2.9- \\
4.7\end{array}$ & $10-14$ & $31-41$ & $\begin{array}{l}1.2- \\
1.4\end{array}$ & $\begin{array}{l}3.2- \\
3.8\end{array}$ & $\begin{array}{l}6.0- \\
9.0\end{array}$ & $7.0-12$ & \begin{tabular}{|c|}
$0.46-$ \\
0.53 \\
\end{tabular} & $\begin{array}{l}5.8- \\
6.5\end{array}$ & $\begin{array}{c}0.27- \\
0.32\end{array}$ & $\begin{array}{l}3.5- \\
3.9\end{array}$ \\
\hline $0.05 \%$ DES & $\begin{array}{c}5.1- \\
5.9\end{array}$ & $\begin{array}{l}5.1- \\
6.1\end{array}$ & 73-77 & $73-82$ & $\begin{array}{l}3.9- \\
4.2\end{array}$ & $\begin{array}{c}3.0- \\
4.4\end{array}$ & $14-24$ & 23-27 & $\begin{array}{c}5.1- \\
5.5\end{array}$ & $\begin{array}{c}8.6- \\
8.9\end{array}$ & $\begin{array}{l}3.0- \\
3.3\end{array}$ & $\begin{array}{c}5.2- \\
5.4\end{array}$ \\
\hline $0.1 \% \mathrm{DES}$ & $\begin{array}{c}4.8- \\
5.6\end{array}$ & $\begin{array}{c}6.0- \\
6.8\end{array}$ & $61-68$ & $90-99$ & $\begin{array}{c}3.8- \\
4.0\end{array}$ & $\begin{array}{c}4.0- \\
4.3\end{array}$ & $13-20$ & $16-29$ & $\begin{array}{l}5.0- \\
5.3\end{array}$ & $\begin{array}{c}9.0- \\
9.6\end{array}$ & $\begin{array}{l}3.0- \\
3.2\end{array}$ & $\begin{array}{c}5.4- \\
5.8\end{array}$ \\
\hline $0.2 \%$ DES & $\begin{array}{l}4.2- \\
5.1\end{array}$ & $\begin{array}{c}5.8- \\
6.8\end{array}$ & $47-52$ & $91-110$ & $\begin{array}{c}3.6- \\
3.8\end{array}$ & $\begin{array}{c}4.0- \\
4.4\end{array}$ & $8.0-20$ & $16-20$ & $\begin{array}{l}4.7- \\
5.0\end{array}$ & $\begin{array}{l}9.9- \\
10.3\end{array}$ & $\begin{array}{l}2.8- \\
3.0\end{array}$ & $\begin{array}{l}5.9- \\
6.2\end{array}$ \\
\hline $0.3 \%$ DES & $\begin{array}{c}3.6- \\
5.2\end{array}$ & $\begin{array}{l}7.0- \\
7.6\end{array}$ & $40-52$ & $97-104$ & $\begin{array}{l}3.1- \\
3.3\end{array}$ & $\begin{array}{l}5.7- \\
6.9\end{array}$ & $10-18$ & 14-18 & $\begin{array}{c}4.4- \\
4.7\end{array}$ & $\begin{array}{c}11.7- \\
12.3 \\
\end{array}$ & $\begin{array}{l}2.6- \\
2.8\end{array}$ & $\begin{array}{l}7.0- \\
7.4\end{array}$ \\
\hline $\begin{array}{l}0.05 \\
\text { DEA }\end{array}$ & $\begin{array}{l}4.3- \\
5.9\end{array}$ & $\begin{array}{c}5.2- \\
6.8\end{array}$ & $69-77$ & $87-96$ & $\begin{array}{l}3.7- \\
4.2\end{array}$ & $\begin{array}{l}4.6- \\
5.3\end{array}$ & $12-25$ & $15-21$ & $\begin{array}{l}4.1- \\
4.4\end{array}$ & $\begin{array}{l}8.6- \\
8.8\end{array}$ & $\begin{array}{l}2.5- \\
2.7\end{array}$ & $\begin{array}{l}5.2- \\
5.3\end{array}$ \\
\hline $0.1 \%$ DEA & $\begin{array}{l}4.2- \\
5.9\end{array}$ & $\begin{array}{l}6.3- \\
6.8 \\
\end{array}$ & $65-78$ & $92-105$ & $\begin{array}{c}3.0- \\
4.5 \\
\end{array}$ & $\begin{array}{l}5.0- \\
5.5\end{array}$ & $12-24$ & $14-22$ & $\begin{array}{l}4.0- \\
4.3 \\
\end{array}$ & $\begin{array}{l}9.3- \\
9.5\end{array}$ & $\begin{array}{l}2.4- \\
2.6 \\
\end{array}$ & $\begin{array}{l}5.7- \\
5.9\end{array}$ \\
\hline $0.2 \%$ DEA & $\begin{array}{l}4.3- \\
5.7 \\
\end{array}$ & $\begin{array}{l}6.4- \\
7.9 \\
\end{array}$ & $51-67$ & $\begin{array}{l}102- \\
127\end{array}$ & $\begin{array}{l}3.2- \\
3.8 \\
\end{array}$ & $\begin{array}{l}6.3- \\
6.7 \\
\end{array}$ & $12-23$ & $12-22$ & $\begin{array}{l}3.9- \\
4.2 \\
\end{array}$ & $\begin{array}{c}10.2- \\
10.4 \\
\end{array}$ & $\begin{array}{l}2.3- \\
2.5 \\
\end{array}$ & $\begin{array}{l}6.1- \\
6.3 \\
\end{array}$ \\
\hline $0.3 \%$ DEA & $\begin{array}{c}4.3- \\
5.2\end{array}$ & $\begin{array}{l}6.5- \\
7.8\end{array}$ & $43-48$ & $95-110$ & $\begin{array}{l}3.0- \\
3.2\end{array}$ & $\begin{array}{l}6.9- \\
7.0\end{array}$ & $12-17$ & 11-18 & $\begin{array}{c}3.8- \\
4.0\end{array}$ & $\begin{array}{c}12.1- \\
12.5\end{array}$ & $\begin{array}{l}2.3- \\
2.4\end{array}$ & $\begin{array}{l}7.3- \\
7.5\end{array}$ \\
\hline $\begin{array}{c}\text { Original } \\
\text { cultivar } \\
\text { Eggseed-1 }\end{array}$ & $\begin{array}{l}4.9- \\
5.9\end{array}$ & $\begin{array}{l}5.2- \\
5.8\end{array}$ & $86-95$ & $84-95$ & $\begin{array}{l}3.0- \\
3.3\end{array}$ & $\begin{array}{l}4.6- \\
5.0\end{array}$ & 16-27 & $16-27$ & $\begin{array}{c}10.8- \\
11.9\end{array}$ & \begin{tabular}{|l|}
$11.0-$ \\
11.2
\end{tabular} & $\begin{array}{l}6.4- \\
6.8\end{array}$ & $\begin{array}{l}6.6- \\
6.7\end{array}$ \\
\hline Polled data & $\begin{array}{l}1.8- \\
5.9 \\
\end{array}$ & $\begin{array}{l}2.9- \\
7.9 \\
\end{array}$ & $10-95$ & $31-127$ & $\begin{array}{l}1.2- \\
4.5 \\
\end{array}$ & $\begin{array}{l}3.2- \\
7.0 \\
\end{array}$ & $6-27$ & $7-29$ & \begin{tabular}{|c|}
$0.46-$ \\
11.9 \\
\end{tabular} & $\begin{array}{l}5.8- \\
12.5 \\
\end{array}$ & \begin{tabular}{|c|}
$0.27-$ \\
6.8 \\
\end{tabular} & $\begin{array}{l}3.5- \\
7.5 \\
\end{array}$ \\
\hline
\end{tabular}

\section{Gy: gamma-rays.}

DES: di-ethyl sulphate.

DEA: di(2-chloro ethyl) amine. 
Hemada, A. A. et al.

11 
J. Plant Production, Mansoura Univ., Vol. 3 (11), November, 2012

12

2693 


\section{Correlation coefficients}

\subsection{Fresh yield:}

Fresh yield of garlic is equal to weight of both top-growth plus bulb. The phenotypic correlation between fresh yield and other tested traits are shown in (Tables 13 and 14). In the first mutant generation (M1V1) of Balady cultivar, fresh yield was correlated significantly with neck diameter, bulb diameter, germination percentage, clove weight and number of leaves. In the other side, the highest correlated traits in the second mutant generation (M1V2) were neck diameter, chlorophyll a, bulb diameter, carotenoids, and clove weight in descending order.

Regarding the first mutant generation-vegetative (M1V1) of cv. Egaseed-1, there was a highly positive relationship between fresh yield and numbers of leaves, germination percentage, plant height, number of cloves per bulb, carotenoids and bulb diameter in descending order. While, fresh yield in the M1V2 of the same population was positively correlated with plant height $(r=0.830)$, neck diameter $(r=0.790)$, clove weight $(r=0.753)$, bulb diameter $(r=0.749)$ and chlorophyll a $(r=0.697)$.

The simple correlation coefficient values for the first mutantvegetative generation "M1V1" of both populations are presented in Table (13 ). The results indicated that positive correlations were exist between fresh yield and each of germination percentage, number of leaves, plant height, and bulb diameter. In the second mutant-vegetative generation "M1V2", high positive correlations were observed between fresh yield and each of chlorophyll b, bulb diameter and plant height. Such relationships should be considered by garlic breeders when selecting for fresh yield character. It is worth mentioning here that plant height and bulb diameters were the highly correlated characteristics in the M1V1 and M1V2 populations. Significant correlation between fresh yield and plant height was reported by Kassahum et al. (2010) and Singh et al. (2011).

\subsection{Cured yield}

Yield after curing in the M1V2 of Balady population was highly correlated with neck diameter $(r=0.870)$, bulb diameter $(0.829)$, germination percentage $(r=0.815)$, clove weight $(r=0.721)$, number of leaves per plant $(r=0.797)$, plant height $(r=0.781)$, chlorophyll $b(r=0.753)$, and chlorophyll a $(r=0.624)$. In the second mutant-vegetative generation "M1V2" of the same population, three characters had highly significant correlation coefficients with the cured yield. These three traits with their corresponding " $r$ " values were neck diameter $(r=0.830)$, chlorophyll a $(r=0.775)$ and bulb diameter $(r=$ 0.742 ). These results may facilitate selections within large population for this character. Baiday and Tiwari (1995) reported that garlic yield was highly correlated with bulb and neck diameters. They suggested that both traits should be considered in the selection for improved bulb yield in garlic. Meanwhile, the correlation coefficient values in the first and second mutantvegetative generations of Egaseed 1 population were varied (Table 14). In the M1V1 generation, three traits were highly correlated with cured yield. These characters were number of leaves, germination percentage and plant height. On the other side, five traits (plant height, clove weight, number of leaves per plant, chlorophyll a and bulb diameter) were highly correlated with 
cured yield. This indicates that improvement through selection may be feasible through indirect selection for more than one trait simultaneously (Singh et al., 2011)

The results of the correlation coefficients across both populations in the first and second generations of Egassed-1 cultivar confirmed the previous conclusion as shown in (Table 14). Germination\%, number of leaves, bulb diameter, and plant height were highly correlated with cured yield in the M1V1 generation. On the other hand, clove weight, bulb diameter, chlorophyll a and neck diameter were highly correlated with the cured yield.

Based on the previous results, it is expected that improvement in number of leaves per plant, plant height and bulb diameter will bring simultaneous improvement in garlic yield.

Consistent values of the correlation coefficients in M1V1 and M1V2 generations may arise through close genetic linkage of factors, pleiotropy or even the parallel response to the prevailing environmental growing conditions. However, variability in the "M1V2" generation was expected to be much lower than that in the first mutant generation "M1V1". Thus, as shown previously the range values for each character were varied considerably between both generations. However, most of the differences between minimum and maximum values for each M1V1 treatments in each population were higher than that of M1V2 generation.

\section{Recommendations}

The following are recommendations for mutation induction in pre-planting treatments of garlic cloves in cvs. Balady and Egaseed-1:

- The dose rate recommended for gamma-radiations from 60 Cobalt source is $1-5$ Gy.

- Chemical mutagenesis can be used to induce genetic variability in both populations.

- Use of number of leaves, plant height and bulb diameter as a selection index could improve garlic productivity in both cultivars.

- By using these mutagens, useful mutant varieties could be developed in garlic.

Table 13. Estimates of phenotypic correlation coefficients between fresh yield and the other studied variables in the first (M1V1) and second (M2V2) mutant generations of two garlic populations.

\begin{tabular}{|c|c|c|c|c|c|c|}
\hline \multirow{2}{*}{ Variable } & \multicolumn{2}{|c|}{ Balady population } & \multicolumn{2}{|c|}{ Egaseed population } & \multicolumn{2}{|c|}{ Both populations } \\
\hline & M1V1 & M1V2 & M1V1 & M1V2 & M1V1 & M1V2 \\
\hline Germination, \% & $0.818^{\star \star}$ & $-0.063^{n s}$ & $0.771^{\star \star}$ & $-0.383^{n s}$ & $0.794^{\star \star}$ & $-0.250^{n s}$ \\
\hline Plant height, $\mathrm{cm}$ & $0.773^{\star *}$ & $0.572^{*}$ & $0.743^{\star *}$ & $0.830^{* *}$ & $0.728^{\star \star}$ & $0.685^{\star \star}$ \\
\hline Leaves number & $0.797^{\star *}$ & $0.524^{\mathrm{ns}}$ & $0.864^{\star \star}$ & $0.654^{*}$ & $0.791^{\star \star}$ & $0.466^{*}$ \\
\hline Chlorophyll a & $0.592^{*}$ & $0.787^{* *}$ & $0.509^{\mathrm{ns}}$ & $0.697^{\star *}$ & $0.540^{*}$ & $0.730^{\star *}$ \\
\hline Chlorophyll b & $0.741^{\star *}$ & $0.170^{\mathrm{ns}}$ & $0.480^{\mathrm{ns}}$ & $0.628^{*}$ & $0.603^{*}$ & $0.390^{\mathrm{ns}}$ \\
\hline Carotene & $0.565^{\star}$ & $0.601^{*}$ & $0.576^{*}$ & $0.517^{*}$ & $0.525^{\star}$ & $0.465^{\star}$ \\
\hline Clove weight, g & $0.799^{\star *}$ & $0.590^{*}$ & $0.462^{\mathrm{ns}}$ & $0.753^{\star \star}$ & $0.409^{n s}$ & $0.480^{*}$ \\
\hline Cured bulb weight, $\mathrm{g}$ & $0.807^{*}$ & $0.503^{\text {ns }}$ & 0.756 & $0.835^{\circ}$ & $0.775^{*}$ & $0.638^{* *}$ \\
\hline Bulb Diameter, cm & $0.826^{\star \star}$ & $0.758^{\star \star}$ & $0.517^{*}$ & $0.749^{\star \star}$ & $0.659^{\star \star}$ & $0.702^{\star \star}$ \\
\hline Neck diameter, cm & $0.872^{\star *}$ & $0.837^{* *}$ & $0.430^{\mathrm{ns}}$ & $0.790^{\star \star}$ & $0.569^{*}$ & $0.569^{*}$ \\
\hline Cloves number & $0.709^{* *}$ & $0.218^{\mathrm{ns}}$ & $0.623^{\star \star}$ & $0.280^{\mathrm{ns}}$ & $0.357^{\mathrm{ns}}$ & $0.137^{\mathrm{ns}}$ \\
\hline Cured yield & $0.996^{\star *}$ & $0.998^{\star *}$ & $0.999^{\star \star}$ & $0.931^{* *}$ & $0.956^{\star *}$ & $0.882^{\star *}$ \\
\hline
\end{tabular}


Hemada, A. A. et al.

ns, *, ** insignificant, significant and highly significant correlation coefficients, respectively.

Table 14. Estimates of phenotypic correlation coefficients between cured yield and the other studied variables in the first (M1V1) and second (M2V2) mutant generations of two garlic populations.

\begin{tabular}{|c|c|c|c|c|c|c|}
\hline \multirow[b]{2}{*}{ Variable } & \multicolumn{2}{|c|}{ Balady population } & \multicolumn{2}{|c|}{ Egaseed population } & \multicolumn{2}{|c|}{ Both population } \\
\hline & M1V1 & M1V2 & M1V1 & M1V2 & M1V1 & M1V2 \\
\hline Germination, \% & $0.815^{\star *}$ & $-0.065^{n s}$ & $0.775^{\star \star}$ & $-0.355^{n s}$ & $0.778^{* *}$ & $-0.234^{n s}$ \\
\hline Plant height, $\mathrm{cm}$ & $0.781^{\star \star}$ & $0.557^{*}$ & $0.752^{\star *}$ & $0.764^{\star \star}$ & $0.639^{* *}$ & $0.515^{\star}$ \\
\hline Leaves number & $0.797^{* *}$ & $0.509^{\mathrm{ns}}$ & $0.866^{\star \star}$ & $0.691^{\star *}$ & $0.686^{\star *}$ & $0.291^{\mathrm{ns}}$ \\
\hline Chlorophyll a & $0.624^{* *}$ & $0.775^{\star *}$ & $0.508^{\mathrm{ns}}$ & $0.655^{\star *}$ & $0.555^{\star}$ & $0.692^{* *}$ \\
\hline Chlorophyll b & $0.753^{\star *}$ & $0.159^{\mathrm{ns}}$ & $0.475^{\mathrm{ns}}$ & $0.621^{*}$ & $0.590^{*}$ & $0.385^{\mathrm{ns}}$ \\
\hline Carotene & $0.593^{*}$ & $0.584^{*}$ & $0.577^{\star}$ & $0.389^{\mathrm{ns}}$ & $0.439^{*}$ & $0.196^{\mathrm{ns}}$ \\
\hline Clove weight, $\mathrm{g}$ & $0.804^{\star \star}$ & $0.571^{*}$ & $0.467^{\mathrm{ns}}$ & $0.741^{\star \star}$ & $0.589^{*}$ & $0.739^{\star \star}$ \\
\hline Cured bulb weight, $g$ & $0.690^{* *}$ & $0.485^{\mathrm{ns}}$ & $0.762^{* *}$ & $0.702^{* *}$ & $0.751^{* *}$ & $0.715^{* *}$ \\
\hline Bulb Diameter, cm & $0.829^{\star \star}$ & $0.742^{\star \star}$ & $0.511^{\mathrm{ns}}$ & $0.637^{* \star}$ & $0.642^{\star *}$ & $0.736^{\star \star}$ \\
\hline Neck diameter, cm & $0.870^{* *}$ & $0.830^{\star *}$ & $0.431^{\mathrm{ns}}$ & $0.612^{*}$ & $0.558^{*}$ & $0.629^{\star \star}$ \\
\hline Cloves number & $0.721^{* *}$ & $0.205^{\mathrm{ns}}$ & $0.620^{*}$ & $0.096^{\mathrm{ns}}$ & $0.124^{\mathrm{ns}}$ & $-0.151^{\mathrm{ns}}$ \\
\hline Cured yield & $0.996^{* *}$ & $0.998^{\star \star}$ & $0.999^{\star *}$ & $0.931^{\star *}$ & $0.956^{\star *}$ & $0.882^{\star \star}$ \\
\hline
\end{tabular}

\section{REFERENCES}

Agrawal, M.K, M.S. Fageria and R.S. Dhaka(2003). Garlic breeding. Agric. Rev., 24(1): 70:74.

Ammar, A.Y.M.(2007). Some studies on improving garlic productivity M.Sc. Thesis, Fac. of Agric. Minia Univ. Egypt.

Alvarez, R.B.;F.Delgado de la Flor (1996). Evaluation of population of garlic (Allium sativum L.) cv. morado Arequipeno irradiation with gamma rays. Rivista di Agricoltura Subtropicale e Tropicale 90:3, 369:377.

Acquaah, G.(2012). Principles of plant genetics and breeding (2 $2^{\text {nd }}$ ed.) John Wiley Sons, LTD. The Atrium Southern Gate, Chichester, West Sussex, PO19 8 SO,UK.

Badr, H.M.M.A. El-Sahl and M.M.Abdel-Kader(1978). Effect of low doses of gamma radiation on the growth and yield of two varieties of tomato (Lycopersicen essulentum, Mill) Alex. J. AgrlC. Res. 26 (3): 715:720.

Baidy, A.C. and R.S. Tiwari (1995). Character association and evaluation of garlic (Allium sativum L.) germplasm. Recent Horti. 2(2): 117-133.

Batchvarov, S.(1993). Garlic Allium sativum L. in: G Kalloo and B.O.Bergh (eds). Genetic improvement of vegetable crops. Pergamon press (pp. 15-27).

Duhova, V.,M.Milkovicova and B. Bohova (1990). Cytogenetic effect of nitrosoethy \& urea (NEU) and sodium azide (SA) on garlic (Allium sativum L.). Acta,Genetica Vol.21:31-38.

Gomez,k.A. and A.A. Gomez(1984). Statistical procedures for agriculture research. John Wiley \& Sons New York pp.680.

Hammad, AH.A.,A.K. Abd El-Halem, I. O. A. Orabi and M.M. Hussein(1988). Effect of gamma - irradiation and salinity in growth, yield and its 
components and chemical composition of Barly. J. Agron. Egypt. 13 (12): $101-114$.

Iglesias Enriquez, I.; T. Rubio Cabello, J. Espinosa and R. Danes(2001). Study of transportation of onion and garlic imported from Chile, irradiation and without irradiation. Alimentaria 38: 325, 79-83.

Joshi, N. , A. Ravindran and V. Mahajan (2011). Investigations on chemical mutagen sensitivity in onion (Allium cepa L.). Int. J. Bot., 7(3): 243-248.

Kassahum, T.T. Akhilesh and W. Kebede (2010). Genetic variability, correlation and path coefficient among bulb yield traits in Ethiopian garlic germplasm. Indian Journal of Horticulture Vol. 64(4):489-499.

Kumar, N. and R.S.Tiwari (1998). Effect of gamma rays irradiation on yield and yield contributing characters of garlic Allium sativum L. genotypes.

Metwally, E.I. and M.E. El-Denary (2003). Evaluation of AVRDC international garlic collection under Egypt condition. Acta Horti. 604, ISHS, Abst.

Metwally, E.I. and A.A. Abou Shousha (2002). Improvement of Egyptian garlic through induce mutation and clonal selection. $2^{\text {nd }}$ Inter. Conf. Hort. Sci., 10-12. Sept. Kafr El- Sheikh, Tanta Univ. Egypt, 28(3): 632638.

MSTAT C, (985). A software program for the design, management and analysis of agronomic research experiments (Version) Michigan State University.

Novak, F.J.(1991). In vitro mutation system for crop improvement. In: plant mutation breeding for crop improvement. Vol. 2, IAEA, Vienna. pp.327342.

Raj,N. and A.A. Khan(2002). A study on genetic parameters in garlic (Allium sativum L.). Horti. J. 15(1): 75-80.

Robbelan, G.(1957). Untersuchugen au strahlen induzierten Blattarbumutanten Van Arobidopsis Thliana L. Vere bungslehere 88:189 (Eng. Summary).

Shalaby, G. I., A,M, Nassar and M.A.Farghaly (1983a). Effect of ENS on yield and quality of Egyptian garlic Assiut J. Agric. Sci.; 14 (4) : 15:26.

Shalaby, G. I., A,M, Nassar and M.A.Farghaly (1983b). Effect of gamma rays on garlic Assiut J. Agric. Sci.; 14 (1) : 71:79.

Singh, R.K.,B.K. Dubey, S. R. Bhonde and R.P.Gupa (2011). Correlation and path coefficient studies in garlic (Allium sativum L.) . Journal of Spices and Aromatic Crops Vol. 20(2) 81-85.

Shashidhar,T.R.;P.R. Dhamati and T.E. Nagaraja (2005). Determination of Ld50 for physical mutagen in garlic cv. Vannur Local. Karnataka J. Horti. 1:2, 110-111.

Shu, Q.Y. (2009). Induce plant mutations in the genomic era. Food Agriculture Organization of the United Nations, Rome, 262-265. 
Hemada, A. A. et al.

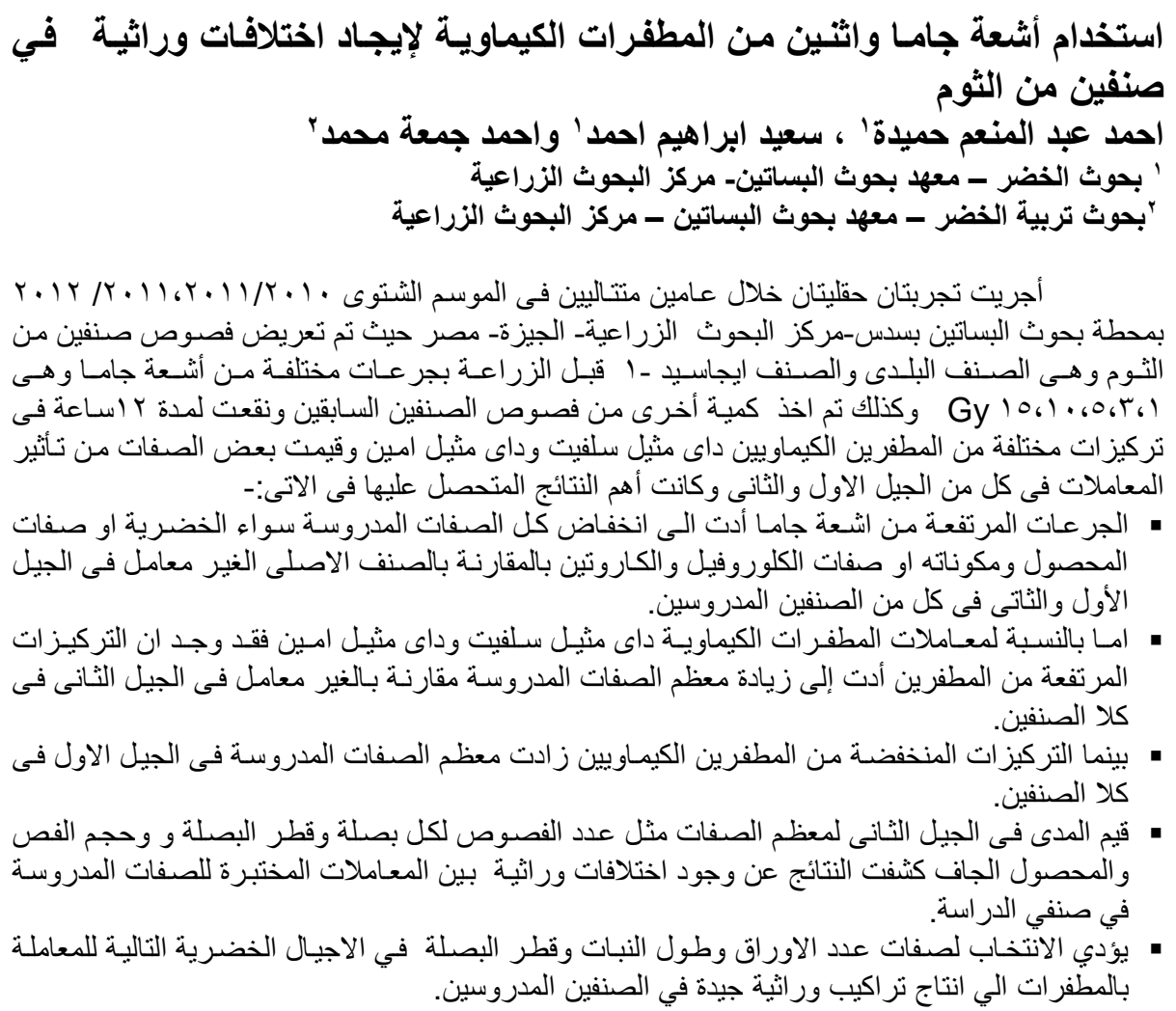

كلية الزراعة - جامعة المنصورة

قام بتحكيم البحث

مركز البحوث الزراعيه

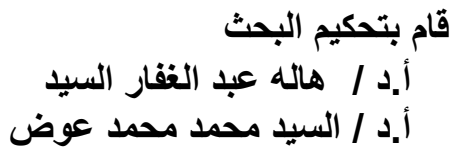


J. Plant Production, Mansoura Univ., Vol. 3 (11), November, 2012

2699 
Table 11. Effect of treatments with gamma-rays and di-ethyl sulphate (DES) and di(2-chloro ethyl) amine (DEA) on pigments contents of garlic cultivar "Balady" in M1V1 in 2010/ 2011 and M1V2 in 2011/2012 .

\begin{tabular}{|c|c|c|c|c|c|c|c|c|c|c|c|c|}
\hline \multirow[t]{2}{*}{ Treatments } & \multicolumn{2}{|c|}{$\begin{array}{c}\text { Cured bulb diameter } \\
\mathbf{c m})\end{array}$} & \multicolumn{2}{|c|}{$\begin{array}{l}\text { Cured bulb } \\
\text { Weight (g) }\end{array}$} & \multicolumn{2}{|c|}{$\begin{array}{l}\text { Clove weight } \\
(\mathrm{g})\end{array}$} & \multicolumn{2}{|c|}{$\begin{array}{c}\text { Number of } \\
\text { cloves / plant }\end{array}$} & \multicolumn{2}{|c|}{$\begin{array}{l}\text { Fresh yield } \\
\text { ton /fed. }\end{array}$} & \multicolumn{2}{|c|}{$\begin{array}{c}\text { Cured yield } \\
\text { Ton /fed. }\end{array}$} \\
\hline & M1V1 & M1V2 & M1V1' & M1V2 & M1V1 & M1V2 & M1V1 & M1V2 & M1V1 & M1V2 & M1V1 & M1V2 \\
\hline 1 Gy & $4.3 \mathrm{C}$ & $5.3 \mathrm{CD}$ & $49.2 \mathrm{D}$ & $55.9 \mathrm{D}$ & $1.7 \mathrm{BC}$ & $2.3 \mathrm{D}$ & $25.0 \mathrm{~B}$ & $28.3 \mathrm{C}$ & $6.5 \mathrm{~B}$ & $10.9 \mathrm{AB}$ & $2.6 \mathrm{~B}$ & $5.4 \mathrm{AB}$ \\
\hline 3 Gy & $4.1 \mathrm{DE}$ & $5.0 \mathrm{CDE}$ & $39.1 \mathrm{E}$ & $49.7 \mathrm{E}$ & $1.4 \mathrm{E}$ & $2.2 \mathrm{D}$ & $25.7 \mathrm{~B}$ & $26.7 \mathrm{CD}$ & $5.2 \mathrm{BC}$ & $10.7 \mathrm{AB}$ & $4.4 \mathrm{~A}$ & $5.3 \mathrm{AB}$ \\
\hline 5 Gy & $3.9 \mathrm{E}$ & $4.9 \mathrm{DE}$ & $21.0 \mathrm{H}$ & $39.5 \mathrm{~F}$ & $1.0 \mathrm{G}$ & $1.9 \mathrm{E}$ & $20.0 \mathrm{C}$ & $20.3 \mathrm{~F}$ & $4.2 \mathrm{BC}$ & $8.9 \mathrm{D}$ & $1.4 \mathrm{~F}$ & $4.5 \mathrm{D}$ \\
\hline 10 Gy & $2.9 \mathrm{H}$ & $2 \mathrm{G}$ & $16.5 \mathrm{I}$ & $27.2 \mathrm{G}$ & $0.8 \mathrm{H}$ & $1.6 \mathrm{~F}$ & $16.0 \mathrm{E}$ & $18.7 \mathrm{~F}$ & $0.633 \mathrm{D}$ & $7.5 \mathrm{~F}$ & $0.300 \mathrm{G}$ & $3.8 \mathrm{~F}$ \\
\hline 15 Gy & 2.31 & $4.1 \mathrm{G}$ & $8.5 \mathrm{~J}$ & $18.0 \mathrm{H}$ & 0.61 & $1.2 \mathrm{G}$ & $13.7 \mathrm{E}$ & $11.0 \mathrm{G}$ & $0.453 \mathrm{D}$ & $6.4 \mathrm{G}$ & $0.210 \mathrm{G}$ & $3.3 \mathrm{G}$ \\
\hline $0.05 \%$ DES & $5.1 \mathrm{AB}$ & $5.1 \mathrm{CD}$ & $67.2 \mathrm{~B}$ & $82.2 \mathrm{C}$ & $1.9 \mathrm{~A}$ & $2.4 \mathrm{D}$ & $15.8 \mathrm{E}$ & $35.8 \mathrm{~A}$ & $5.4 \mathrm{BC}$ & $8.5 \mathrm{DE}$ & $2.4 \mathrm{BC}$ & $4.3 \mathrm{DE}$ \\
\hline $0.1 \%$ & $5.0 \mathrm{AB}$ & & $62.1 \mathrm{C}$ & $66.0 \mathrm{BC}$ & $1.7 \mathrm{BC}$ & $2.6 \mathrm{C}$ & $25.0 \mathrm{~B}$ & $35.7 \mathrm{~A}$ & $5.0 \mathrm{BC}$ & $9.0 \mathrm{D}$ & $2.3 \mathrm{C}$ & $4.4 \mathrm{DE}$ \\
\hline $0.2 \% \mathrm{D}$ & $9 \mathrm{~B}$ & $5.6 \mathrm{AB}$ & $48.7 \mathrm{D}$ & $66.9 \mathrm{BC}$ & $1.5 \mathrm{DE}$ & $2.7 \mathrm{BC}$ & $21.4 \mathrm{C}$ & $31.7 \mathrm{~B}$ & $4.4 \mathrm{BC}$ & $9.9 \mathrm{C}$ & $1.9 \mathrm{D}$ & $4.9 \mathrm{C}$ \\
\hline $0.3 \%$ DES & $4.0 \mathrm{DE}$ & $5.9 \mathrm{~A}$ & $33.8 \mathrm{~F}$ & $67.5 \mathrm{BC}$ & $1.2 \mathrm{~F}$ & $2.8 \mathrm{AB}$ & $19.4 \mathrm{CD}$ & $26.6 \mathrm{CD}$ & $4.3 \mathrm{BC}$ & $10.2 \mathrm{BC}$ & $1.9 \mathrm{D}$ & $5.1 \mathrm{BC}$ \\
\hline $0.05 \%$ DEA & $4.2 \mathrm{CD}$ & $4.5 \mathrm{FG}$ & $67.4 \mathrm{~B}$ & $62.6 \mathrm{C}$ & $1.8 \mathrm{AB}$ & $2.3 \mathrm{D}$ & $26.1 \mathrm{~B}$ & $32.4 \mathrm{~B}$ & $4.0 \mathrm{BC}$ & $7.5 \mathrm{~F}$ & $1.8 \mathrm{DE}$ & $3.7 \mathrm{~F}$ \\
\hline $0.1 \%$ & $F$ & $F$ & $.1 \mathrm{E}$ & $3.4 \mathrm{C}$ & 1.6 & $2.4 \mathrm{D}$ & $25.7 \mathrm{~B}$ & $24.0 \mathrm{DE}$ & & $8.1 \mathrm{EF}$ & $1.7 \mathrm{DE}$ & $4.0 \mathrm{EF}$ \\
\hline $0.2 \%$ DEA & $7 \mathrm{~F}$ & $4.7 \mathrm{EF}$ & $34.6 \mathrm{~F}$ & $66.1 \mathrm{BC}$ & $1.4 \mathrm{E}$ & $2.6 \mathrm{C}$ & $24.8 \mathrm{~B}$ & $25.5 \mathrm{E}$ & $3.6 \mathrm{BC}$ & $8.3 \mathrm{DE}$ & $1.6 \mathrm{EF}$ & $4.2 \mathrm{DE}$ \\
\hline $0.3 \%$ DEA & $3.4 \mathrm{G}$ & $5.1 \mathrm{CD}$ & $26.9 \mathrm{G}$ & $69.1 \mathrm{~B}$ & $1.1 \mathrm{FG}$ & $2.9 \mathrm{~A}$ & $16.8 \mathrm{DE}$ & $23.2 \mathrm{E}$ & $3.2 \mathrm{CD}$ & $11.3 \mathrm{~A}$ & $1.4 \mathrm{~F}$ & $5.7 \mathrm{~A}$ \\
\hline $\begin{array}{c}\text { Original cultivar } \\
\text { Balady }\end{array}$ & $5.2 \mathrm{~A}$ & $5.2 \mathrm{CD}$ & $81.5 \mathrm{~A}$ & $82.4 \mathrm{~A}$ & $1.9 \mathrm{~A}$ & $2.0 \mathrm{E}$ & $34.4 \mathrm{~A}$ & $31.9 \mathrm{~B}$ & $10.1 \mathrm{~A}$ & $10.4 \mathrm{BC}$ & $4.5 \mathrm{~A}$ & $5.2 \mathrm{BC}$ \\
\hline
\end{tabular}

Means within each column followed by the same letter are not statistically different at 0.05 level (Duncan's range test).

Gy: gamma-rays.

DES: di-ethyl sulphate.

DEA: di(2-chloro ethyl) amine 
Table 12. Effect of treatments with gamma - rays and di - ethyl sulphate (DES) and di (2-chloro ethyl) amine (DEA) on pigmentscontents of garlic cultivar "Egaseed-1" in M1V1 in 2010/2011 and M1V2 in 2011/2012

\begin{tabular}{|c|c|c|c|c|c|c|c|c|c|c|c|c|}
\hline \multirow[t]{2}{*}{ Treatments } & \multicolumn{2}{|c|}{$\begin{array}{l}\text { Cured bulb } \\
\text { diameter cm) }\end{array}$} & \multicolumn{2}{|c|}{$\begin{array}{l}\text { Cured bulb } \\
\text { Weight (g) }\end{array}$} & \multicolumn{2}{|c|}{$\begin{array}{c}\text { Clove weight } \\
\text { (g) }\end{array}$} & \multicolumn{2}{|c|}{$\begin{array}{c}\text { Number of } \\
\text { cloves / plant }\end{array}$} & \multicolumn{2}{|c|}{$\begin{array}{l}\text { Fresh yield } \\
\text { ton /fed. }\end{array}$} & \multicolumn{2}{|c|}{$\begin{array}{c}\text { Cured yield } \\
\text { Ton /fed. }\end{array}$} \\
\hline & M1V1 & M1V2 & M1V1' & M1V2 & M1V1 & M1V2 & M1V1 & M1V2 & M1V1 & M1V2 & M1V1 & M1V2 \\
\hline $1 \mathrm{~Gy}$ & $3.6 \mathrm{E}$ & $5.6 \mathrm{D}$ & $630 \mathrm{C}$ & $88.4 \mathrm{D}$ & $3.6 \mathrm{D}$ & $4.9 \mathrm{E}$ & $17.0 \mathrm{BC}$ & 17.7 CD & $7.9 \mathrm{~B}$ & $11.8 \mathrm{~B}$ & $4.8 \mathrm{~B}$ & $7.1 \mathrm{~B}$ \\
\hline $3 \mathrm{~Gy}$ & $3.6 \mathrm{E}$ & $5.3 \mathrm{DE}$ & $37.9 \mathrm{~F}$ & $66.5 \mathrm{~F}$ & $2.4 \mathrm{~F}$ & $4.0 \mathrm{G}$ & 14.7 DE & 16.0 DE & $5.5 \mathrm{C}$ & $7.7 \mathrm{~F}$ & $3.3 \mathrm{C}$ & $5.3 \mathrm{~F}$ \\
\hline 5 Gy & $3.4 \mathrm{~F}$ & $5.0 \mathrm{E}$ & $33.1 \mathrm{~F}$ & $65.9 \mathrm{~F}$ & $2.2 \mathrm{~F}$ & $3.9 \mathrm{GH}$ & $13.7 \mathrm{E}$ & 16.0 DE & $4.9 \mathrm{DE}$ & $8.0 \mathrm{G}$ & 2.9 DEF & $4.8 \mathrm{G}$ \\
\hline 10 Gy & $2.9 \mathrm{G}$ & $4.3 \mathrm{~F}$ & $20.1 \mathrm{G}$ & $52.8 \mathrm{G}$ & $1.7 \mathrm{G}$ & $3.8 \mathrm{HI}$ & $10.7 \mathrm{~F}$ & $13.0 \mathrm{~F}$ & $0.830 \mathrm{~J}$ & $6.7 \mathrm{H}$ & \begin{tabular}{|l|}
$0.490 \mathrm{I}$ \\
\end{tabular} & $4.1 \mathrm{H}$ \\
\hline $15 \mathrm{~Gy}$ & $2.9 \mathrm{G}$ & $3.9 \mathrm{~F}$ & $12.3 \mathrm{H}$ & $35.3 \mathrm{H}$ & $1.3 \mathrm{H}$ & $3.4 \mathrm{~J}$ & $7.7 \mathrm{G}$ & $9.3 \mathrm{G}$ & $0.500 \mathrm{~J}$ & 6.11 & \begin{tabular}{|l|}
$0.300 \mathrm{I}$ \\
\end{tabular} & $3.7 \mathrm{~J}$ \\
\hline $0.05 \%$ DES & $5.5 \mathrm{~A}$ & $5.5 \mathrm{D}$ & $74.5 \mathrm{~B}$ & $76.8 \mathrm{E}$ & $5.0 \mathrm{~A}$ & 3.71 & 18.7 AB & $24.8 \mathrm{~A}$ & $5.3 \mathrm{CD}$ & $8.8 \mathrm{~F}$ & $3.2 \mathrm{CD}$ & $5.3 \mathrm{~F}$ \\
\hline $0.1 \%$ DES & $5.2 \mathrm{BC}$ & $6.4 \mathrm{BC}$ & $64.3 \mathrm{C}$ & $93.9 \mathrm{CD}$ & $4.9 \mathrm{AB}$ & $4.2 \mathrm{~F}$ & 15.8 CD & $23.0 \mathrm{~B}$ & 5.1 CD & $9.3 \mathrm{E}$ & 3.1 CDE & 3.91 \\
\hline $0.2 \%$ DES & $4.6 \mathrm{D}$ & $6.6 \mathrm{~B}$ & $55.9 \mathrm{D}$ & $98.3 \mathrm{BC}$ & $4.7 \mathrm{~B}$ & $4.2 \mathrm{~F}$ & 14.5 DE & 17.8 CD & 4.9 DEF & 10.1 D & $2.9 \mathrm{EF}$ & $6.1 \mathrm{D}$ \\
\hline $0.3 \%$ DES & $4.4 \mathrm{D}$ & $7.3 \mathrm{~A}$ & $45.8 \mathrm{E}$ & 99.7 BC & $3.2 \mathrm{E}$ & $6.1 \mathrm{C}$ & $13.5 \mathrm{E}$ & 15.9 DE & 4.6 EFG & $11.9 \mathrm{~B}$ & 2.7 FG & $7.2 \mathrm{~B}$ \\
\hline $0.05 \%$ DEA & $5.4 \mathrm{AB}$ & $6.1 \mathrm{C}$ & $73.5 \mathrm{~B}$ & 91.7 CD & $4.9 \mathrm{AB}$ & $4.8 \mathrm{E}$ & $20.3 \mathrm{~A}$ & $18.4 \mathrm{C}$ & $4.3 \mathrm{GHI}$ & $8.7 \mathrm{~F}$ & $2.9 \mathrm{GH}$ & $5.2 \mathrm{~F}$ \\
\hline $0.1 \%$ DEA & $5.0 \mathrm{C}$ & $6.5 \mathrm{BC}$ & $70.2 \mathrm{~B}$ & $96.6 \mathrm{BCD}$ & $4.3 \mathrm{C}$ & $5.2 \mathrm{D}$ & 18.8 AB & $18.2 \mathrm{C}$ & 4.4 FGH & $9.4 \mathrm{E}$ & $2.5 \mathrm{GH}$ & $5.7 \mathrm{E}$ \\
\hline $0.2 \%$ DEA & $4.5 \mathrm{D}$ & $7.1 \mathrm{~A}$ & 60.7 CD & $111.3 \mathrm{~A}$ & $3.7 \mathrm{D}$ & $6.5 \mathrm{~B}$ & $17.0 \mathrm{BC}$ & 16.7 CD & $4.0 \mathrm{HI}$ & $10.3 \mathrm{D}$ & $2.4 \mathrm{H}$ & $6.2 \mathrm{D}$ \\
\hline $0.3 \%$ DEA & $4.6 \mathrm{D}$ & $7.2 \mathrm{~A}$ & $45.7 \mathrm{E}$ & $103.7 \mathrm{~B}$ & $3.5 \mathrm{D}$ & $6.9 \mathrm{~A}$ & 14.4 DE & $14.7 \mathrm{E}$ & 3.91 & $12.3 \mathrm{~A}$ & $2.3 \mathrm{H}$ & $7.4 \mathrm{~A}$ \\
\hline \begin{tabular}{|c|} 
Original cultivar \\
Eggaseed -1
\end{tabular} & $5.5 \mathrm{~A}$ & $5.2 \mathrm{DE}$ & $90.7 \mathrm{~A}$ & $89.9 \mathrm{D}$ & $3.0 \mathrm{E}$ & $4.8 \mathrm{E}$ & $18.1 \mathrm{~B}$ & $18.1 \mathrm{C}$ & $11.3 \mathrm{~A}$ & $11.1 \mathrm{C}$ & $6.6 \mathrm{~A}$ & $6.6 \mathrm{C}$ \\
\hline
\end{tabular}

Means within each column followed by the same letter are not statistically different at 0.05 level (Duncan's range test).

Gy: gamma-rays. DES: di-ethyl sulphate. DEA: di(2-chloro ethyl) amine 
Hemada, A. A. et al. 